\title{
Changes on the $\mathrm{CO}_{2}$ dynamic in near-surface cavities under a future warming scenario:
}

\section{factors and evidences from field and experimental findings}

\author{
C. Pla ${ }^{1,2 *}$; S. Cuezva ${ }^{3,4}$; E. Garcia-Anton ${ }^{3}$; A. Fernandez-Cortes ${ }^{3,5}$; J.C. Cañaveras 1,2; S. Sanchez-Moral ${ }^{3}$; \\ D. Benavente ${ }^{1,2}$.
}

(1) Departamento de Ciencias de la Tierra y del Medio Ambiente. Universidad de Alicante. San Vicente del Raspeig, 03690

(Alicante), Spain.

(2) Laboratorio de Petrología Aplicada. Unidad Asociada CSIC-Universidad de Alicante. San Vicente del Raspeig , 03690 (Alicante), Spain.

(3) Museo Nacional de Ciencias Naturales (CSIC). José Gutiérrez Abascal 2, 28006 Madrid, Spain.

(4) Geomnia Natural Resources SLNE, 28006, Madrid, Spain.

(5) Department of Earth Sciences, Royal Holloway, University of London, Egham, Surrey TW20 OEX, UK.

*Corresponding author: c.pla@ua.es

Departamento de Ciencias de la Tierra y del Medio Ambiente. Universidad de Alicante. San Vicente del Raspeig, 03690 (Alicante), Spain. Telephone: +34965903400 ext. 2095 . 


\section{Abstract}

This study is based in a field monitoring of a cave-soil-atmosphere system validated with laboratory experimentation. $\mathrm{CO}_{2}$ and ${ }^{222} \mathrm{Rn}$ dynamics in the cavity demonstrate the dependence on the climatic parameters, mainly on the differences between outdoor and indoor temperatures. Within the cave, the annual cycles are characterized by two outstanding moments: cave gaseous recharge and ventilation when cave acts as gaseous sink or source respectively. Relationship with soil above the cave exists permanently. Soil temperature and moisture are responsible for $\mathrm{CO}_{2}$ production at different time scales. Soil $\mathrm{CO}_{2}$ in Rull site reaches values higher than $3000 \mathrm{ppm}$ in April-May, which falls to nearly $1000 \mathrm{ppm}$ during the summer time. Due to $\mathrm{CO}_{2}$ diffusion, maximum values in the cave are reached in the warmest months and are in accordance to soil $\mathrm{CO}_{2}$ values. Within the cave, maximum $\mathrm{CO}_{2}$ concentration is, in average, $3470 \mathrm{ppm}$ while minimum is $623 \mathrm{ppm}$. Cave temperature and relative humidity remain quite stable with mean values of $16.1{ }^{\circ} \mathrm{C}$ and $97.9 \%$ respectively. To describe field findings, $\mathrm{CO}_{2}$ production and diffusion experiments are developed related to soil behaviour. Results show that soil $\mathrm{CO}_{2}$ production increases as soil temperature and moisture increase according to a calculated logarithmic equation until water content in soil exceeds the saturation values. In addition, $\mathrm{CO}_{2}$ diffusion in Rull soil is reduced around $60 \%$ when water content in soil increases from 0 to $30 \%$. Soil-produced $\mathrm{CO}_{2}$ reaches Rull cave, by diffusion. We estimate $57 \mathrm{~kg}$ of emitted $\mathrm{CO}_{2}$ from the cave to the atmosphere in an annual cycle, considering a volume of $9915 \mathrm{~m}^{3}$. Finally, projections of future climate in the study site confirm a general tendency for annual-mean conditions to be warmer and drier, which will directly affect soil $\mathrm{CO}_{2}$ production. Under this situation, Rull cave will experience changes in the stored and then exchanged annual amount of $\mathrm{CO}_{2}$.

\section{Key words}

$\mathrm{CO}_{2}$ source, $\mathrm{CO}_{2}$ sink, $\mathrm{CO}_{2}$ redistribution, soil, underground cave, $\mathrm{CO}_{2}$ future estimations

\section{$\underline{\text { Highlights }}$}

Outdoor atmosphere, soil/rock membrane and underground atmosphere are closely related

Climatic parameters regulate when subterranean environments act as $\mathrm{CO}_{2}$ sink or source 
$\mathrm{CO}_{2}$ diffusion recharges the cave and falls as soil water content increases

Soil $\mathrm{CO}_{2}$ concentration is parameterized as function of soil moisture and temperature

Future predictions about climatic change may consider caves as natural $\mathrm{CO}_{2}$ sources 


\section{Introduction}

Shallow caves are distributed widely across continental ecosystems and contain significant volume of underground air with high concentrations of soil-derived $\mathrm{CO}_{2}$ (Wood, 1985; Bourges et al., 2001, 2014; Faimon et al., 2006; Cuezva et al., 2011; Fernandez-Cortes et al., 2011, 2015a; Garcia-Anton et al., 2014). In particular, karst ecosystems are characterized by an inherent high capacity for gas exchange with the atmosphere. The continuous balances calculated for the $\mathrm{CO}_{2}$ increases due to anthropogenic emissions do not coincide with those observed in the atmosphere, demonstrating the existence of a significant terrestrial missing sink (Tans et al., 1990; Houghton et al., 1998). Some initial studies highlighted the potential contribution of the carbonate dissolution processes to this "unknown" sink (Liu and Zhao, 2000; Gombert, 2002), however, it has been traditionally neglected or underestimated in studies about net carbon balance in terrestrial ecosystems (Serrano-Ortiz et al., 2010). The ongoing interest in below-ground $\mathrm{CO}_{2}$ capture and storage, as one potential mitigation strategy to reduce the human $\mathrm{CO}_{2}$ atmospheric emissions, has underlined the need for more knowledge regarding the geological storage capacity (Post et al., 2012; Nickerson and Risk, 2013). Although estimations about the net contribution of karst areas to the global carbon cycle is still under debate (Liu and Zhao, 2000; Liu et al., 2010; Serrano-Ortiz et al., 2010; Martin et al., 2013; White, 2013; Fernandez-Cortes et al., 2015b; Milanolo and Gabrovsek, 2015) there is evidence of their role acting $\mathrm{CO}_{2}$ sources and sinks.

In the underground karstic caves, the stored air is $\mathrm{CO}_{2}$ enriched due to, among other principal contributors, natural fluxes associated with direct diffusion and/or convection from soil and $\mathrm{CO}_{2}$ related to ground air zone, formed by the decay of organic matter washed down into the unsaturated zone (Mattey et al., 2016). $\mathrm{CO}_{2}$ dissolution in water filling the soil-epikarst pore space, results in $\mathrm{CO}_{2}$ degassing from drip water that also contributes to increases in cave air $\mathrm{CO}_{2}$ content.

Soil is the terrestrial ecosystem component that emits the largest $\mathrm{CO}_{2}$ fluxes (Ryan and Law, 2005; Goffin et al., 2014). Caves participate in the redistribution of this soil $\mathrm{CO}_{2}$, acting as temporary $\mathrm{CO}_{2}$ reservoirs at certain periods. $\mathrm{CO}_{2}$ fluxes are the result of the soil-produced $\mathrm{CO}_{2}$ then transported from the place of production. Both processes conform soil respiration, which closely depends on atmospheric conditions. Furthermore, soil and chemical properties, microbial and root activities and activities from macro- and microfauna are essential controllers as well (Zanchi et al., 2014). 
Many studies have found that soil respiration is closely related with soil temperature and moisture and this is because biological activities in soil are strongly affected by the environmental factors (Fang et al., 1998; Gulledge and Schimel, 2000; Lavigne et al., 2004; Badia et al., 2013; Sun et al., 2013; Chang et al., 2014). Small changes in ecosystem respiration due to climate change may alter the amount of emitted $\mathrm{CO}_{2}$. Directly according to this, atmospheric and underground $\mathrm{CO}_{2}$ concentrations will also vary. Considering a future insight, there is no clear response to predictions about variations in $\mathrm{CO}_{2}$ but nowadays it is becoming a crucial step quantifying how ecosystem respiration will respond to environmental perturbations (Xu et al., 2004).

The existing narrow relationships between outdoor atmosphere, the soil/rock membrane and the underground atmosphere constitute a multicomponent system that works in accord. Variations in one of the components will reflect the effect in the others. As consequence, optimal research in how all the components are related and their response to the controllers, will allow estimating more precise variations related to future climate change.

The monitoring of underground environments is a key factor to understand the processes. Cave climate and, particularly, cave temperature is usually considered relatively stable (Bourges et al., 2006; Ravbar and Kosutnik, 2013). If soil temperature is a principal controller of soil respiration, differences between outdoor and cave temperature are essential in the role of the cave acting as $\mathrm{CO}_{2}$ source or sink (Faimon et al., 2006; Benavente et al., 2011; Sanchez-Cañete et al., 2013; Mattey et al., 2016). The understanding of all the interactions will derive in more accurate determinations of the interchanged amount of $\mathrm{CO}_{2}$ towards the annual cycles, specially with a view to detecting changes in $\mathrm{CO}_{2}$ contributions to the global carbon cycle.

The aim of this paper is to quantify the mechanisms and evaluate the environmental factors that control the gas transport through soils and rocks and their implication in the balance of atmospheric $\mathrm{CO}_{2}$. Results of the study pretend to highlight the main drivers in this multicomponent system. To achieve this goal a comprehensive monitoring of climatic, cave air and soil parameters was used to capture the response of the $\mathrm{pCO}_{2}$ in underground air to changes in outdoor and soil conditions. Both, cave and soil, follow cyclic and repetitive seasonal behaviour, which allows understanding the guidelines of their interaction and their possible response versus future climatic changes. The field results were treated and filtered by discrete wavelet transform and then related to laboratory results. Laboratory 
experiments were specially designed to understand the soil response to changes in temperature and soil moisture, representing field conditions. Finally, we evaluate the estimated evolution of $\mathrm{CO}_{2}$ concentration according to predictions of future climate change. $\mathrm{CO}_{2}$ concentration is parameterized via a logarithmic expression of moisture and soil temperature obtained through the laboratory experiment and validated with field data.

\section{Methodology}

\subsection{Site Information}

The field data sets analysed in this study were produced from the continuous measurements performed in Rull cave ( $38^{\circ} 48^{\prime} 40^{\prime \prime} \mathrm{N} ; 0^{\circ} 10^{\prime} 38^{\prime \prime} \mathrm{W}$ ), in the south-eastern area of Spain (Alicante province) (Pla et al., 2015). The cave is located in massive Miocene conglomerates, with considerable textural and petrophysical complexity, which were deposited on Cretaceous limestones. The relative thickness of the overlying host rock varies from 9 to 23 metres. The soil profile above the cave has a thickness of about 1 $\mathrm{m}$ with fine to coarse texture and no differentiated horizons. The vegetation consists of C3 plants, which are distributed in the form of Mediterranean shrubs (Chamaerops humilis, Osyris quadripartite, Rosmarinus officinalis, Erica multiflora, Cistus albidus, Ulex parviflorus). Rull cave area is defined by a Mediterranean sub-humid climate (Rivas-Martinez, 1983). A nearly 3-year record (December 2012 January 2016) reveals that mean value of annual precipitation in Rull cave was $457 \mathrm{~mm}$. Averaged temperatures varied from $10.4{ }^{\circ} \mathrm{C}$ in the coldest months to $30.1{ }^{\circ} \mathrm{C}$ in summer. Inside the cave there is predominance of thermo-hygrometric stability, even with the presence of visitors (average annual value of 13074 people in the period 2013-2015). Mean temperature inside the cavity was $16.4^{\circ} \mathrm{C}$ with thermal amplitude lower than $0.5^{\circ} \mathrm{C}$. The gaseous regimen in the indoor atmosphere is characterized by annual cycles with two main stages (Pla et al., 2016a). Throughout the outgassing stage the connexion between the underground and the outdoor atmosphere predominates and the gaseous interchange is allowed. Thus a ventilation process (temperature-driven air flow) is responsible for the gaseous removal from the cavity when the cave temperature is higher than the outdoor temperature. $\mathrm{CO}_{2}$ and ${ }^{222} \mathrm{Rn}$ concentration in this stage had an average value of $623 \mathrm{ppm}$ and $712 \mathrm{~Bq} \mathrm{~m} \mathrm{~m}^{-3}$ respectively (Figure 2). During the warmest season, when outdoor temperature is higher than the cave temperature, the cavity suffers an isolation stage; the gaseous interchange is limited and, as consequence, the gaseous concentration 
increases sharply. Mean $\mathrm{CO}_{2}$ and ${ }^{222} \mathrm{Rn}$ concentrations were $3544 \mathrm{ppm}$ and $3195 \mathrm{~Bq} \mathrm{~m}^{-3}$ respectively (Figure 2).

\subsection{Field sampling}

\subsubsection{Environmental measurements}

Standard microclimatic and meteorological parameters were measured continuously from December 2012 to January 2016. Inside the cavity, the monitoring station was composed by an 8-channel, 16-bit datalogger (COMBILOG TF 1020, Theodor Fiedrich \& Co., Germany) with a suite of probes. Particularly, a non-dispersive infrared analyser, (ITR 498, ADOS (Germany)) 0-10000 ppm measurement range and $0.3 \%$ accuracy with a suction pump, was used to measure $\mathrm{CO}_{2}$ concentrations. Air temperature and relative humidity were measured by a HygroClip S3 sensor (Pt100 1/10 DIN temperature sensor and Rotronic humidity sensor). Measurement ranges were from -40 to $100{ }^{\circ} \mathrm{C}$ and $0-100 \%$ with accuracies of $\pm 0.10^{\circ} \mathrm{C}$ and $\pm 0.8 \%$ respectively. Atmospheric pressure was measured with a silicon capacitive sensor Vaisala BAROCAP-PTB 100 (Finland) with a measure range and accuracy of 800-1100 $\pm 0.3 \mathrm{hPa}$. The station scanned each sensor every $10 \mathrm{~s}$ and recorded the 15-min averages. Radon concentrations were determined with a Radim 5WP Radon monitor (SMM Company, Prague, Czech Republic). The device was designed to support high humidity conditions. This monitor determines radon concentration by measuring gross $\alpha$-activity of the radon decay products $218 \mathrm{Po}$ and $214 \mathrm{Po}$, collected electrostatically on the surface of a Si-semiconductor. The lowest detectable activity is $80 \mathrm{~Bq} \mathrm{~m}^{-3}$, for 1-h measurements with a statistical error equal to $\pm 20 \%$, and the maximum is $150 \mathrm{kBq} \mathrm{m}{ }^{-3}$. Outside the cave, a weather station (HOBO U30, Onset, Bourne, MA, USA) with an array of sensors was employed to record atmospheric conditions (air temperature, relative humidity and barometric air pressure with measuring ranges and accuracies of $0-50 \pm 0.03{ }^{\circ} \mathrm{C}, 0-100 \% \pm 0.6 \%$ and 800 to $1100 \pm 0.1$ mbar respectively). Rainfall amount was registered by a 147 RG2-M rain gauge (Onset Computer Corporation, Bourne, MA, USA, resolution $0.2 \mathrm{~mm}$ ). In addition, from February 2015 to January 2016, soil temperature and volumetric content (VWC) were controlled by a HOBO U12 (Onset, Bourne, MA, USA, accuracy $\pm 0.5^{\circ} \mathrm{C}$ ) and by an ECHO EC-5 (Decagon Devices, USA, accuracy 1-2\%) respectively, buried in soil at $20 \mathrm{~cm}$ depth. 


\subsubsection{Gas sampling and analysis}

Discrete air samples were monthly-bimonthly collected from January 2014 to May 2015 in order to characterize the spatial distribution and temporal variations of $\mathrm{CO}_{2}$ concentration in background atmosphere, cave and soil air and its isotopic value, $\delta^{13} \mathrm{CO}_{2}$. Soil air was pumped using micro-diaphragm gas pump (KNF Neuberger, Freiburg, Germany) at $3.1 \mathrm{I} \mathrm{min}^{-1}$ at atmospheric pressure and a steel tube with grooved sides at its ends ( $0.35 \mathrm{~m}$ depth). Exterior air and air from the cave was sampled with an air pump. Air was stored in 1 l Tedlar bags with lock valves and then analysed in a period no longer than $48 \mathrm{~h}$ after sampling using a Picarro G2101-i analyser (California, USA, accuracy of $0.3 \%$ for $\delta^{13} \mathrm{CO}_{2}$ after 5 minutes of analysis) that employs cavity ring-down spectroscopy (CRDS-WS) (Crosson, 2008). The analyser measures the isotopologues of the carbon dioxide $\left({ }^{12} \mathrm{CO}_{2}\right.$ and $\left.{ }^{13} \mathrm{CO}_{2}\right)$ and automatically calculates the isotopic value, $\delta^{13} \mathrm{CO}_{2}$. Further technical specifications and details about the quality control of measurements are described by Garcia-Anton et al. (2014) and Fernandez-Cortes et al. (2015a). The number of analysed samples was 197 (96 from the cavity, 58 from soil air and 46 from exterior atmosphere). The isotopic analyses of $\delta^{13} \mathrm{CO}_{2}$ finished after May 2015. Afterwards, discrete measures of $\mathrm{CO}_{2}$ in the atmosphere and soil were carried out with a Senseair portable $\mathrm{CO}_{2}$ concentration sensor (SenseAir, Sweden, measuring range $0-10000 \mathrm{ppm}$, accuracy $\pm 20 \mathrm{ppm}$ ). To measure $\mathrm{CO}_{2}$ in soil, the soil air was extracted using a microdiaphragm gas pump (KNF Neuberger, Freiburg, Germany) at 3.1 $1 /$ min at atmospheric pressure and a steel tube with grooved sides at its ends. The steel tube was directly connected by using a polyurethane tube, to the gas inlet of the portable probe. In the cave, continuous measurements of $\mathrm{CO}_{2}$ concentration were performed with the microclimatic station and verified with the measurements obtained with the portable probe.

\subsection{3. $24 \mathrm{~h}$ flux campaign}

With the aim to analyse the soil behaviour and its evolution in a $24 \mathrm{~h}$ cycle, a flux campaign was performed in Rull site. In addition, these measurements were accompanied by isotopic measurements to evaluate the relative contributions of diffusion and advection to temporal variations of soil $\mathrm{CO}_{2}$ concentration. The equipment consisted of an automated soil $\mathrm{CO}_{2}$ flux system (Li-8100, Li-Cor, $1.5 \%$ accuracy of $\mathrm{CO}_{2}$ concentration reading) with Long-Term Chamber 8100-104 to make continuous measurements. The chamber was installed over a single PVC collar (20 cm inner diameter), which was 
permanently installed in the soil. The flux sampling, $24 \mathrm{~h}$ length, was developed in July 17,2015 . The Long-Term Chamber was programmed to make 3 consecutive measurements (allowing aeration between them) every hour. Soil $\mathrm{CO}_{2}$ fluxes were estimated using the initial slope of a fitted exponential curve adjusted for the total (chamber and collar) volume. To ensure the validity of the measurements, 3 repetitions of the flux measure were performed every hour and then an average flux value was obtained. This $24 \mathrm{~h}$ campaign was completed with soil $\mathrm{CO}_{2}$ concentration and $\delta^{13} \mathrm{CO}_{2}$ sampling every 2 hours by collecting 1 l Tedlar bag from soil. Inside the cave, continuous measurements of microclimatic parameters were registered while 3 discrete air samples were performed to analyse the $\delta^{13} \mathrm{CO}_{2}$ in cave air.

\subsection{Laboratory experiments}

\subsubsection{Soil properties}

Soil samples were collected from the upper $30-\mathrm{cm}$ layer of Rull cave field site. The soil was prepared following the same procedures in all the experiments. The organic layer and roots were removed and then the soil was dried at $40{ }^{\circ} \mathrm{C}$ during 48 hours. Once removed the $\mathrm{H}$ horizon, the experimentation was performed with the unique existing soil horizon with uniform physical properties.

Physical properties of the soil above Rull cave were determined in order to characterize the soil employed in the laboratory experimentation. Bulk and grain density of soil are respectively 1.3 and 2.36 $\mathrm{g} \mathrm{cm}^{-3}$, with total porosity of $52 \%$. The grain size distribution is: $0.002 \mathrm{~mm}(2.2 \%), 0.063-0.002 \mathrm{~mm}$ (80.1\%) and 2-0.063 mm (17.7\%), i.e., Rull soil is classified as silty/silty-loam soil. Soil is mainly composed by quartz $(70 \%)$, phyllosilicates $(20 \%)$, calcite $(5 \%)$ and feldspars $(5 \%)$. Organic matter content, determined by the Walkley-Black method, is $14.7 \%$.

\subsubsection{Soil column experiments}

To measure $\mathrm{CO}_{2}$ diffusion through soil, a particular laboratory experiment was specially designed for this study (Figure 1). The experiment consisted in a soil column design to perform a gaseous $\mathrm{CO}_{2}$ injection. From a PVC (polyvinyl chloride) pipe a cylinder of $60 \mathrm{~cm}$ long and $22 \mathrm{~cm}$ diameter was obtained. A pair of $3 \mathrm{~cm}$ diameter holes was drilled up along the column with a vertical separation of $32 \mathrm{~cm}$ in order to allocate the sensors. The holes were diametrically distributed avoiding vertical allocation. They were 
designed to hermetically and horizontally positioned one $\mathrm{CO}_{2}(\mathrm{GMP} 222$ Vaisala Carbocap, 0-8000 ppm measurement range, accuracy $\pm 1.5 \%$ ), one temperature (PT-100, accuracy $\pm 0.5^{\circ} \mathrm{C}$ ) and one volumetric water content probe (ECHO EC-5, Decagon Devices, accuracy 1-2\%) at every height poked into the soil and connected to a datalogger (CR-1000 Campbell Scientific). A homogeneous representative field dried sample was packed manually into the PVC piece to accomplish a uniform compaction and create a field analogue sample, trying to match the most similar field conditions. Particular care was considered when compacting the soil to avoid preferential fluxes between the pipe walls and soil. The column was then left to equilibrate for two weeks before the gas experiment started. Similar experiment was successfully developed by O'Brien et al. (2014). The entire soil column was supported by a wire mesh placed in the bottom of the column and, beneath this wire mesh, a homogenization chamber $18 \mathrm{~cm}$ height and the same diameter of the PVC column, was set up. The bottom of the chamber was supplied with an inlet valve in order to allow the $\mathrm{CO}_{2}$ injection. In every experiment $1 \mathrm{l}$ of $\mathrm{CO}_{2}(\mathrm{~g})$ was injected. Gas diffused through the soil column, entering by the wire mesh. The changes with time in $\mathrm{CO}_{2}$ concentrations, temperature and volumetric water content (WVC) were measured with the two different set of probes located at the different heights. In addition, independent measurements of $\mathrm{CO}_{2}$ fluxes $\left(\mu \mathrm{mol} \mathrm{m} \mathrm{m}^{-2} \mathrm{~s}^{-1}\right)$ from soil surface to open atmosphere were obtained continuously using an automated soil $\mathrm{CO}_{2}$ flux system (Li-8100, Li-Cor, $1.5 \%$ accuracy of $\mathrm{CO}_{2}$ concentration reading) with Long-Term Chamber 8100 104, allowing aeration between measurements. The soil column experiments were run twice: with completely dry soil $\left(\mathrm{VWC}=0 \mathrm{~m}^{3} \mathrm{~m}^{-3}\right)$, and with partially wet soil $\left(\mathrm{VWC}=0.16 \mathrm{~m}^{3} \mathrm{~m}^{-3}\right)$. To accomplish the partial wetting, 3.8 I of water were added to soil and homogeneously mixed before filling the pipe. As consequence, water content was uniform in the whole soil column. 

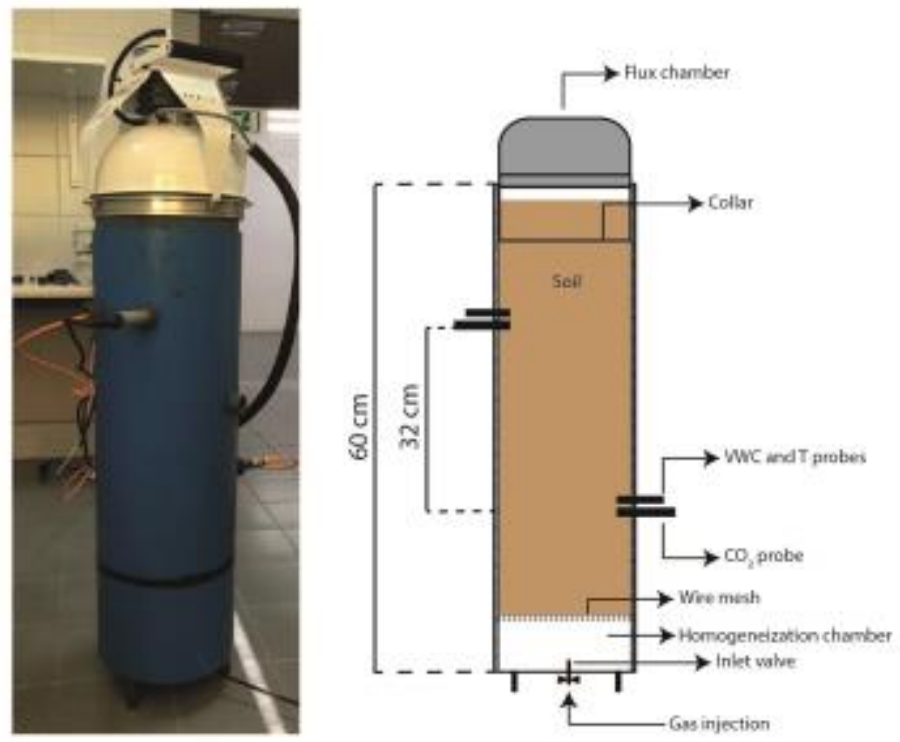

Figure 1. Soil column experimental setup.

\subsubsection{Soil incubation experiments}

In order to understand the effect of soil moisture and temperature variations in the production of soil $\mathrm{CO}_{2}, 12$ soil samples (150 g soil placed in bottles) were added different water amounts and were tested under different temperature cycles in an incubation experiment. To prepare soil samples they were carefully homogenized. Water was added to the mixture, which was weakly stirred in order to accomplish a homogeneous moisture, and then samples were left to equilibrate for $24 \mathrm{~h}$. The different moisture treatments consisted in the addition of $0,10,17,25,32,36,40,45,50,75,95$ and $109 \mathrm{~g}$ of water to the different soil bottles (150 g). Temperature conditions were accomplished by plunging the soil samples in a refrigerated bath circulator (WiseCircu WCR). The 12 samples were tested under two different consecutive cycles (24 $\mathrm{h}$ long approximately in total) of temperature variation. At first, temperature increased from 5 to $30^{\circ} \mathrm{C}$ and following this, temperature decreased from 30 to $5^{\circ} \mathrm{C}$.

Volumetric water content (VWC) and temperature were measured with an ECHO EC-5 (Decagon Devices, accuracy $1-2 \%$ ) and a PT-100 (accuracy $\pm 0.5^{\circ} \mathrm{C}$ ) respectively. $\mathrm{CO}_{2}$ soil concentration from each sample was measured by using a GMP222 (Vaisala Carbocap, 0-8000 ppm, accuracy $\pm 1.5 \%$ ) buried in vertical position mounted in an open-end adapter. 


\subsection{Signal analysis}

Microclimatic signals from Rull cave were filtered by performing wavelet analysis (in particular the discrete wavelet transform (DWT)). The purpose of the filtering was focused on the $\mathrm{CO}_{2}$ signal, and had the objective of removing the effect of the high-frequency events in the signal (essentially the effect of the visitors, as other high frequency events, i.e. precipitation, were scarce in the study area during the recorded period). This allows highlighting the low-frequency events (natural trends) from the signal and thereby extracting more concise conclusions when dealing with the natural processes that occur in the cavity. When subtracting the high-frequency component, some medium-term component may remain into the total $\mathrm{CO}_{2}$ signal due to the effect of visitors. Pla et al. (2016a) demonstrated in Rull site the natural signal trend predominance in the annual record. Therefore, the effect of the medium-term component could be considered as negligible in this study. In addition, the obtained conclusions in the cave, were useful to determine the employed mother wavelet filter and the scale used in DWT analysis (Daubechies 5, which experimentally has been considered appropriate for the study of microclimatic signals and scale 8, which contain 1-year periodicity).

In this study the wavelet analysis was carried out by the MATLAB-based computer code Environmental Wavelet Tool (EWT) (Galiana-Merino et al., 2014).

\section{Results}

\subsection{Gaseous annual variability in Rull site}

The annual cycles of both gases in cave air, $\mathrm{CO}_{2}$ and ${ }^{222} \mathrm{Rn}$, are parallels, without hardly lags between the seasonal maximums and minimums. These cycles define maximum and minimum gaseous concentration in the cave, and related to this, they allow stablishing the recharge-discharge (degassing) stages of the cavity. Figure 2 and Table 1 summarize the microclimatic conditions of the cave and rainfall for the whole period. 


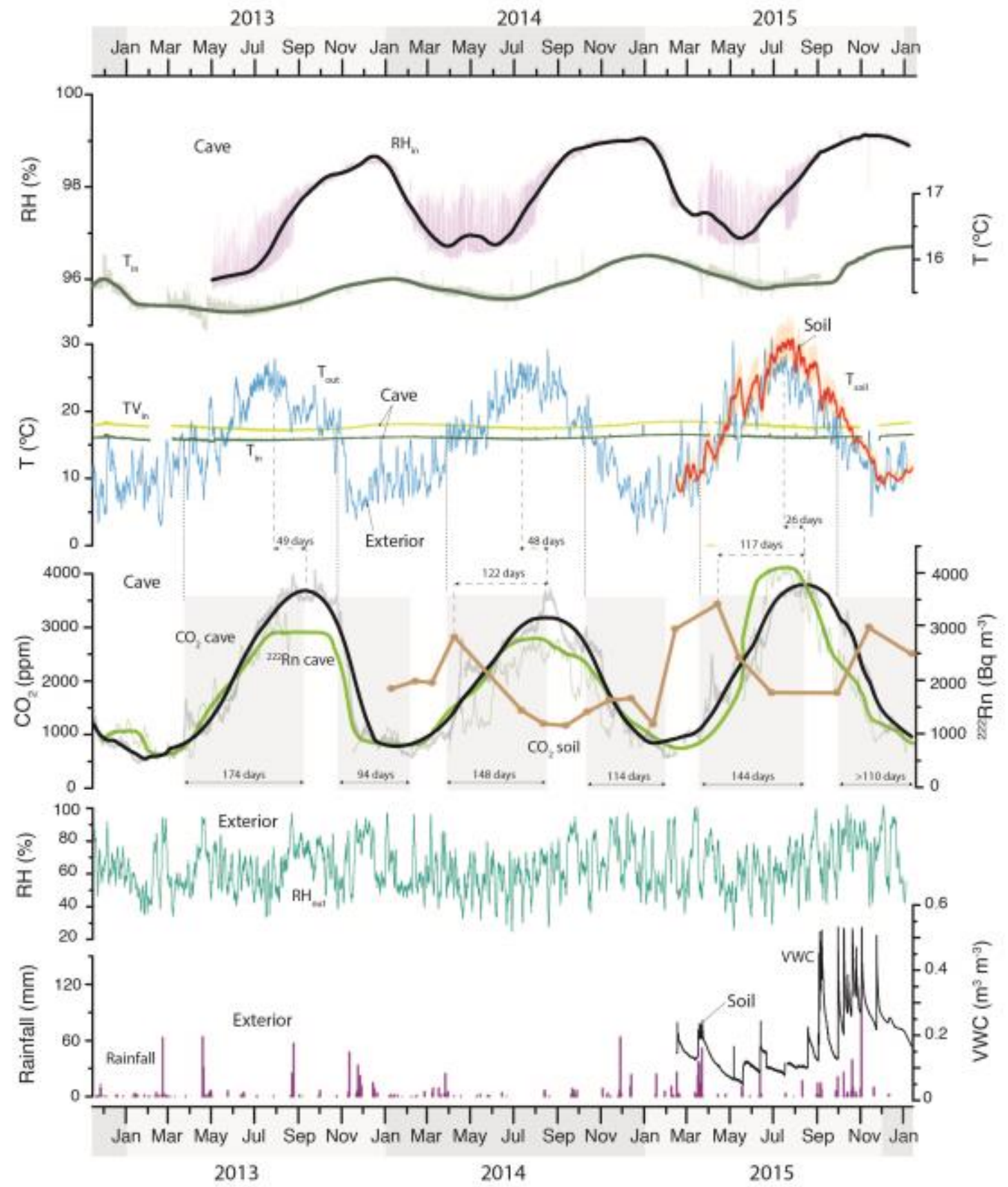

Figure 2. Microclimatic conditions of the cave and the outdoor and soil meteorological parameters for the studied period. Shaded areas in the graph indicate the length of the gaseous recharge and ventilation of the cavity. Dashed lines indicate when the cave changes from recharge state (isolation) to outgassing (ventilation). Period of time between maximum value of $\mathrm{T}_{\text {out }}-\mathrm{T}_{\text {in }}$ difference and maximum value of cave air $\mathrm{CO}_{2}$ and between maximum soil $\mathrm{CO}_{2}$ and cave air $\mathrm{CO}_{2}$ are also indicated (see text and Table 2). Virtual $\mathrm{T}_{\text {in }}$ is calculated in order to detect the effect of the partial $\mathrm{CO}_{2}$ pressures (see text). Thick lines in the signals are the result of DWT filtering. 
The filtered signals (December 2012 - January 2016) are considered to represent the natural processes that occur within the cavity once the high-frequency disturbance has been removed. In the 3-year period, an upward interannual trend is detected in outdoor and indoor temperatures $\left(T_{\text {out }}, T_{\text {in }}\right)$ and most of the parameters, with the exception of $\mathrm{CO}_{2}$ concentration inside the cavity, outdoor relative humidity $\left(\mathrm{RH}_{\text {out }}\right)$ and accumulated rainfall, that differ from the tendency in 2014 . The upward trend (Table 1$)$ is confirmed by the permanent probes installed in the cavity and also by the portable probes used within the field campaigns. Inside the cavity, average value of $\mathrm{T}_{\text {in }}$ and $\mathrm{RH}_{\text {in }}$ increase was $0.2{ }^{\circ} \mathrm{C}$ year ${ }^{-1}$ and $0.3 \%$ year $^{-1}$ in the whole period. $\mathrm{T}_{\text {out }}$ average increase was $0.4^{\circ} \mathrm{C}$ year ${ }^{-1}$.

A key factor in the degassing (ventilation) stage is that clearly the beginning and the end of this stage is stablished by the relationship between $\mathrm{T}_{\text {out }}$ and $\mathrm{T}_{\mathrm{in}}$. Figure 2 shows the results of the temporal variation of soil $\mathrm{CO}_{2}$ and the simultaneous $\mathrm{CO}_{2}$ concentration of the cave air. In a cave, partial pressures of $\mathrm{CO}_{2}$ might be large enough to affect the air density. Therefore, Kowalski and Sanchez-Cañete (2010) proposed the definition for the virtual temperature, which takes into account the heaviness of $\mathrm{CO}_{2}$. As a consequence, the difference between outside and virtual indoor temperate, $\mathrm{TV}_{\mathrm{in}}$, describes the degassing stage rather than $\mathrm{T}_{\text {in }}-\mathrm{T}_{\text {out }}$ relationship. Figure 2 shows a slight delay in the degassing stage considering both $\mathrm{T}_{\text {in }}$ and $\mathrm{TV}_{\text {in }}$. Thus, effect of the partial $\mathrm{CO}_{2}$ pressures in the degassing stage is not determinant in the studied cave and therefore we consider $\mathrm{T}_{\text {out }}$ and $\mathrm{T}_{\text {in }}$ in the calculations.

Maximum values of $\mathrm{CO}_{2}$ concentration in soil for the annual cycles occurred in spring and were 2769 and 3431 ppm (April 2014 and April 2015 respectively). Different factors influenced on the maximum values in soil $\mathrm{CO}_{2}$, such as the vegetation growing, where soil respiration rates are significantly higher (Liu et al., 2016). On the contrary, the lowest $\mathrm{CO}_{2}$ soil concentrations were detected between August and September for the both cycles (1167 and 1778 ppm in 2014 and 2015). Soil CO $_{2}$ maximums and minimums precede maximums and minimums of cave $\mathrm{CO}_{2}$ concentration respectively. Maximum values of soil $\mathrm{CO}_{2}$ occurred in 2014 and 2015, 122 and 117 days in advance to the maximum $\mathrm{CO}_{2}$ concentration of cave air. In addition, for 2013, 2014 and 2015, maximum concentration of cave air $\mathrm{CO}_{2}$ was accomplished 49, 48 and 26 days after the moment of maximum differences between $\mathrm{T}_{\text {out }}$ and $\mathrm{T}_{\text {in }}$ (Table 2). Figure 2 also contains the diary rainfall for the whole period and the soil temperature ( $\left.T_{\text {soil }}\right)$ and VWC for the last ten months of the study. Some differences were found in the rainfall amount during these 3 years. While in the first year the total rainfall amount was $501 \mathrm{~mm}, 2014$ was characterized by having 
the lowest ( $248 \mathrm{~mm}$ ), which supposes more than $50 \%$ of reduction when comparing with both, 2013 and 2015 (2015 was the wettest year with $623 \mathrm{~mm}$ ). Larger soil $\mathrm{CO}_{2}$ concentrations in 2015 seem to be related to this. Even considering the short register of $\mathrm{T}_{\text {soil }}$ and $\mathrm{VWC}$, rises in soil $\mathrm{CO}_{2}$ concentration in 2015 are affected by the occurrence of rainfall episodes (May and October-November 2015), which directly increase soil VWC. Soil temperature follows the same pattern of the atmospheric air temperature $\left(\mathrm{T}_{\text {out }}\right)$ as this is the main influential factor. The lowest $\mathrm{T}_{\text {soil }}$ daily average value $\left(6.8^{\circ} \mathrm{C}\right)$ was registered in February while maximum was registered in the end of July $\left(28.9^{\circ} \mathrm{C}\right) . \mathrm{T}_{\text {soil }}$ directly depends on $\mathrm{T}_{\text {out }}$ with a time mismatch relative to the soil thermal conductivity.

\section{2. $\delta^{13} \mathrm{CO}_{2}$ isotopic signal and $\mathrm{CO}_{2}$ sources}

The soil-cave-atmosphere relationships are established with the results of the air sampling and analyses of the $\mathrm{CO}_{2}$ abundance and its carbon isotopic signature in Rull cave. Carbon dioxide in the soil is mainly derived from two sources: respiration of living plants and decomposition of organic matter by soil microorganisms (Amundson et al., 1998). Although in Rull area, plants contribution to soil respiration might be substantial in the spring (the vegetation growing season might be related to increases in soilproduced $\mathrm{CO}_{2}$ ), in the study area plants are scarce and basically composed by Mediterranean shrubs, which suffer from prolonged dry periods. Matteucci et al. (2015) recently demonstrated that soil respiration estimated for a Mediterranean forest during a dry period was driven mostly by microbial respiration.

Figure 3(a) shows the Keeling plot for Rull samples. The Keeling plot for the analysis of the $\delta^{13} \mathrm{CO}_{2}$ isotopic signal (Keeling, 1958), demonstrates that, in Rull cave air, the $\mathrm{CO}_{2}$ concentration is the result of mixing the background atmospheric $\mathrm{CO}_{2}$ with the soil-produced carbon dioxide. When performing the linear fitting with the annual data, the $y$-intercept value $(-27.00 \%)$ of the Keeling model for Rull samples points to a dominant component of soil organic $\mathrm{CO}_{2}$ originated from soil organic respiration (GarciaAnton et al., 2014). The carbon isotope chemistry of a soil will be therefore the result of the respiration of plant roots and the microbial decomposition of soil organic matter. For C3 plants, the average $\delta^{13} \mathrm{CO}_{2}$ value is $-27 \%$ (Deines, 1980; Amundson et al., 1998). 

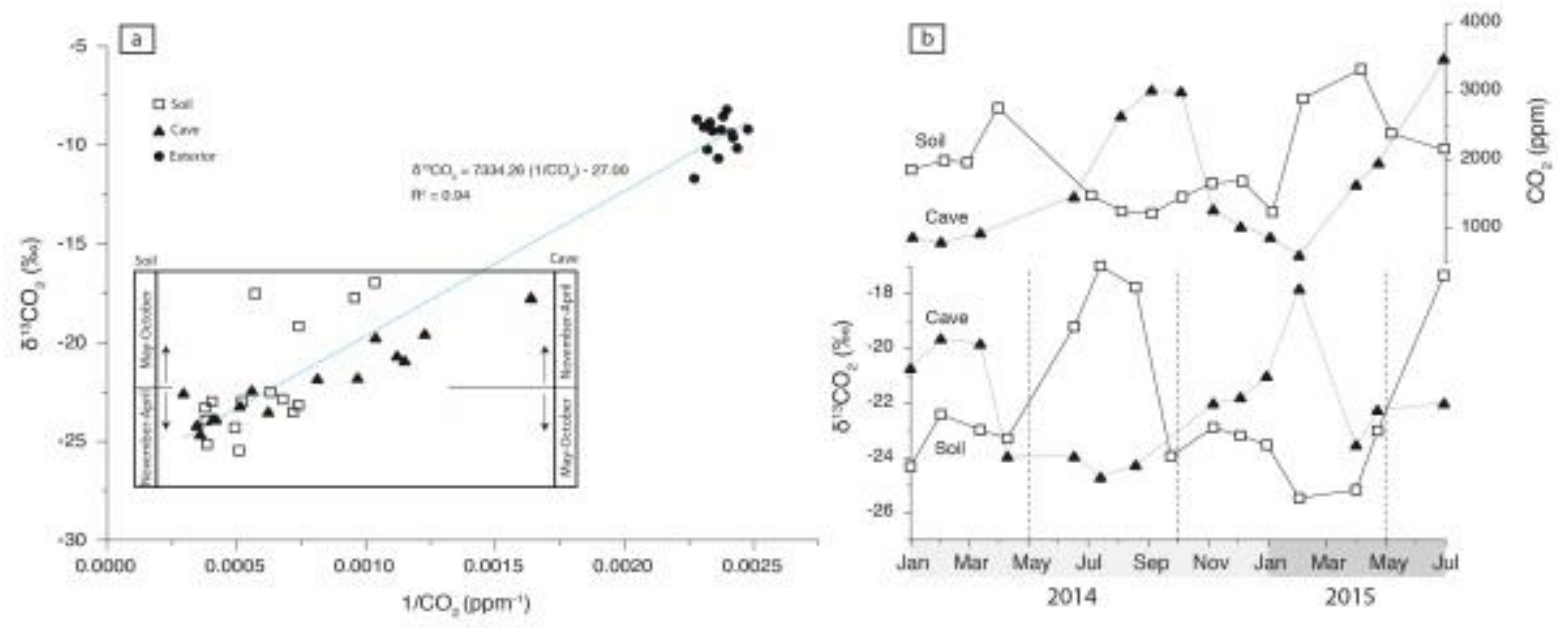

Figure 3. (a) Keeling plot for the discrete sampling (average value from each performed campaign) for Rull soil, exterior air and cave air. Changes in $\delta^{13} \mathrm{CO}_{2}(\% \circ)$ in soil and cave air due to annual cycles are indicated in the frame. (b) Soil and cave $\mathrm{CO}_{2}$ concentration (ppm) and $\delta^{13} \mathrm{CO}_{2}(\% \circ)$. Values obtained from the discrete samples from January 2014 to July 2015. Dashed vertical lines indicate changes in $\delta^{13} \mathrm{CO}_{2}(\% \circ)$ due to annual cycles.

$\delta^{13} \mathrm{CO}_{2}$ measures performed in Rull cave for the period 2014-2015 allow identifying the rechargedischarge (degassing) stages of the cavity. Figure $3(b)$ describes the $\delta^{13} \mathrm{CO}_{2}$ soil and cave annual evolution and $\mathrm{CO}_{2}$ concentration. Soil $\delta^{13} \mathrm{CO}_{2}$ shows a negative relationship with soil $\mathrm{CO}_{2}$ concentration. Decrease in soil $\delta^{13} \mathrm{CO}_{2}$ values (lighter values) points to periods dominated by soil $\mathrm{CO}_{2}$ production. In the cave, heavier $\delta^{13} \mathrm{CO}_{2}$ values are related to a major influence of the external atmosphere, which occurs during the degassing stage (i.e. during the coldest months). Lighter values of $\delta^{13} \mathrm{CO}_{2}$ in the cavity indicate a major influence of the soil-produced $\mathrm{CO}_{2}$, which is predominant in the recharge stage, during the warmest months.

\subsection{Daily variations in soil-produced $\mathrm{CO}_{2}$}

The monitored parameters and the analysis performed in July 2015 in Rull soil for a $24 \mathrm{~h}$ period provided a diary cycle of the soil atmosphere behaviour. Figure 4 shows the daily variations of soil $\mathrm{CO}_{2}$ concentration and fluxes in accordance to $\mathrm{T}_{\text {soil }}$ and VWC. At night, when soil $\mathrm{CO}_{2}$ concentration and flux have lower values, peaks in $\delta^{13} \mathrm{CO}_{2}$ reveal a likely lower activity of soil microorganisms as consequence of the decrease in $\mathrm{T}_{\text {soil. }}$ In the central hours of the day the occurrence of major fluxes and soil $\mathrm{CO}_{2}$ concentrations are related and depend on $\mathrm{T}_{\text {out }}$ and $\mathrm{T}_{\text {soil. }}$. Lighter values of $\delta^{13} \mathrm{CO}_{2}$ imply major activity of soil microorganisms and thus higher $\mathrm{CO}_{2}$ content in soil. In addition, when soil fluxes show maximum 
values (nearly $5 \mu \mathrm{mol} \mathrm{m}{ }^{-2} \mathrm{~s}^{-1}$ ) from 13:30 to $16: 00$, atmospheric air $\delta^{13} \mathrm{CO}_{2}$ reaches more negative values that could be consequence of the soil fluxes influence.

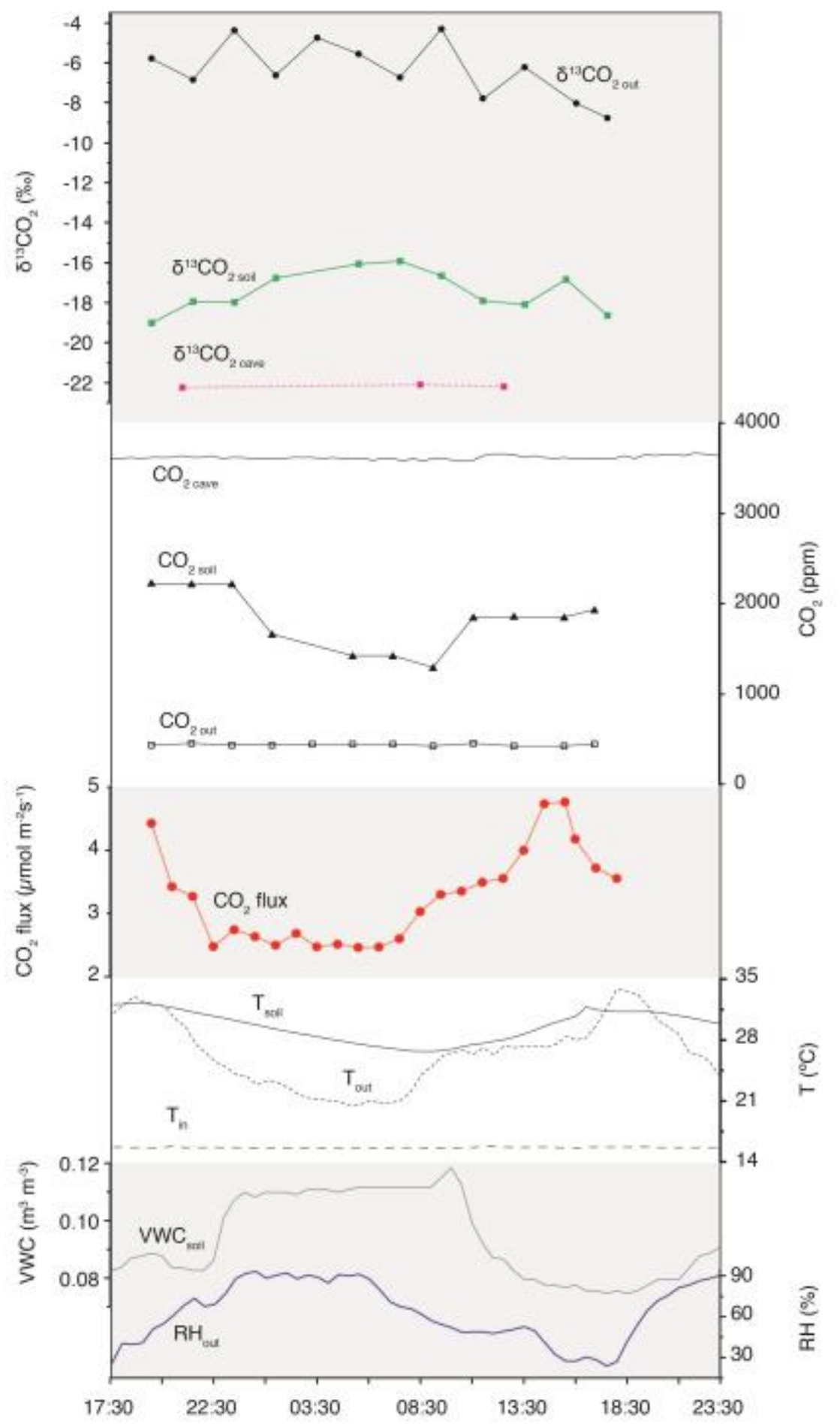

Figure 4. Daily variations of $\mathrm{CO}_{2}$ and $\delta^{13} \mathrm{CO}_{2}$ (outdoor, soil and cave air). Soil $\mathrm{CO}_{2}$ fluxes, outdoor and soil temperatures, soil VWC and outdoor relative humidity and cave temperature in the $24 \mathrm{~h}$ field campaign (17-18 July 2016). 
In the $24 \mathrm{~h}$ campaign major activity of soil microorganisms was found at midday, but in annual time scales and for Rull site, it occurs generally in April-May (Figure 3(b)). If average value of $\delta^{13} \mathrm{CO}_{2}$ within the $24 \mathrm{~h}$ register is compared to annual values, it points to a low soil activity and, in addition, to a ventilated soil air, which matches with the dry state of the soil during the day (high temperatures are responsible for low soil water contents that allow gaseous circulation through the soil porous system). During night, rises in soil VWC are found likely due to dew condensation and relative to the higher $\mathrm{RH}_{\text {out }}$ found at night (up to 90\%). Fernandez-Cortes et al. (2013) demonstrated that water condensation in the porous system is triggered when the partial pressure of vapour in the air exceeds the vapour pressure at the temperature of the soil surface, or at the temperature of the water film previously condensed on the soil surface. Water condensation is more active due to the presence of a pore structure and dissolved salts. In porous materials, such as the studied overlying soil, water condenses at relative humidities $(\mathrm{RH})$ below saturation (100\% relative to a planar water surface). For $\mathrm{RH}$ values between $75-85 \%$ at constant temperatures, the water layers merge into the small pores due to capillary condensation, which is effective for pore radii close to $0.1 \mu \mathrm{m}$. When $\mathrm{RH}$ exceeds $85 \%$, capillary condensation becomes important and a significant increase in soil water content is produced. The grain size distribution and the presence of phyllosilicates in Rull soil indicate the presence of pore size lower than $0.1 \mu \mathrm{m}$, thus, it is feasible that during night, effective condensation in the soil porous system is produced. The same process has been previously identified in other soils above caves (Cuezva et al., 2011). Within a $24 \mathrm{~h}$ period, the temperature decrease at night is responsible for the decline of soil $\mathrm{CO}_{2}$ production.

$\mathrm{CO}_{2}$ concentration in atmospheric air remains almost constant for the whole campaign (average value of $431 \pm 20 \mathrm{ppm}) . \delta^{13} \mathrm{CO}_{2}$ in the atmospheric air showed variations ranging from -4.35 to $-8.82 \%$ with an average value of $-6.71 \%$. Although the annual cycle in Rull cave presents important variations in cave $\mathrm{CO}_{2}$ concentration, in the diary cycle, in this period, no significant differences are detected because $\mathrm{T}_{\text {out }}>$ $\mathrm{T}_{\text {in }}$ and this situation leads to a reduction in the connexion between cave-soil-atmosphere. The discrete measures of cave air $\delta^{13} \mathrm{CO}_{2}$ seem to vary in a weak range, remaining almost constant. The measurement range varied from -22.16 to $-22.23 \%$ and so that no substantial variations of this 
parameter were identified. Cave air $\mathrm{CO}_{2}$ was $3483 \pm 91 \mathrm{ppm}$. The narrow variations in cave air $\delta^{13} \mathrm{CO}_{2}$ and concentration indicate a lack of connection in the gaseous exchange between soil and cave.

\section{4. $\mathrm{CO}_{2}$ diffusion in soil experiments}

In the soil column experiment, $\mathrm{CO}_{2}$ moves through soil pore system by diffusion as consequence of a concentration gradient (Crank, 1956; Rolston and Møldrup, 2002; Risk and Kellman, 2008; Jabro et al., 2012; among others). The experiment performed in the soil columns revealed differences between dry (Figure 5(a)) and wet soil (Figure 5(b)). In both, average $\mathrm{CO}_{2}$ concentration previous to the $\mathrm{CO}_{2}$ injection was 450 and 3070 ppm respectively due to the heterotrophic respiration by microorganisms (Kuzyakov, 2006). In both soils, measured fluxes vary according to oscillations in temperature. In the dry soil column, maximum surface flux was $5.0 \mu \mathrm{mol} \mathrm{m} \mathrm{m}^{-1}$ and was registered 21 hours after the injection. In the wet column a constant VWC $\left(0.16 \mathrm{~m}^{3} \mathrm{~m}^{-3}\right)$ was maintained in soil for the whole experiment since it is a representative value of the mean VWC in Rull soil. Peak value of $\mathrm{CO}_{2}$ flux was $43.1 \mu \mathrm{mol} \mathrm{m} \mathrm{m}^{-2} \mathrm{~s}^{-1}$, registered $27 \mathrm{~h} 30 \mathrm{~min}$ after the injection. Fluxes are much notable in the wet soil, and this is caused for the soil activity, which constantly increases the $\mathrm{CO}_{2}$ concentration in soil. Diffusion coefficient in the wet column has been demonstrated to be lower because the soil water content reduces the available space to gas movement within the soil porous system, which is confirmed with the major times required by the injected gas to reach the soil surface. 

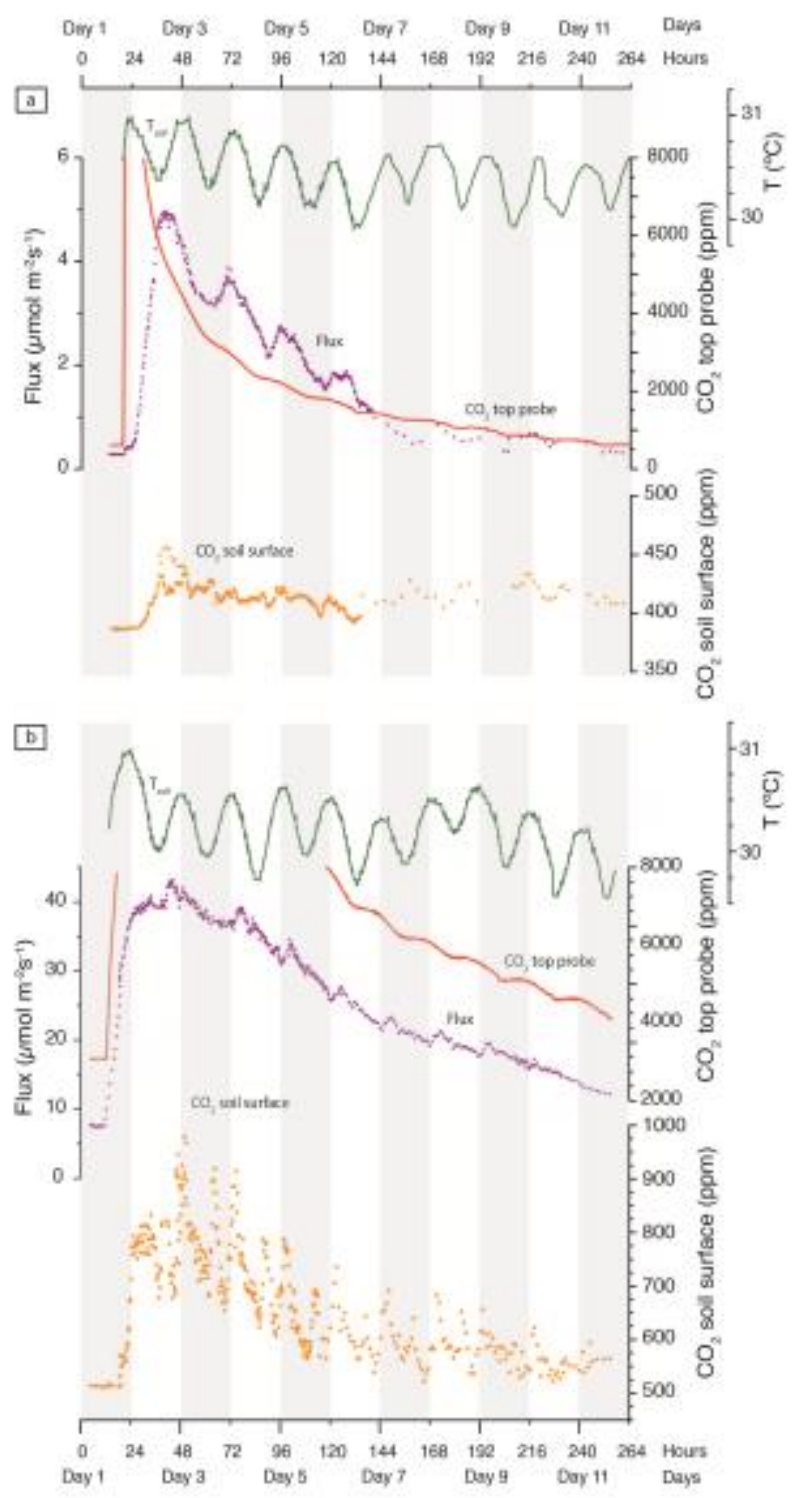

Figure 5. $\mathrm{CO}_{2}$ concentration measured in the flux chamber and with the top sensor. Flux and temperature values measured in the soil column experiments. (a) Dry soil (VWC $\left.=0 \mathrm{~m}^{3} \mathrm{~m}^{-3}\right)$. (b) Wet soil (VWC $\left.=0.16 \mathrm{~m}^{3} \mathrm{~m}^{-3}\right)$. The measures performed in the bottom of the column were higher than $8000 \mathrm{ppm}$ and were out of the probe measurement range for the most of the experiment, thus the data is not showed.

\subsection{Influence of soil temperature and moisture on soil $\mathrm{CO}_{2}$ concentration}

With the incubation experiment, it was found positive correlation of soil $\mathrm{CO}_{2}$ production with the increase of soil temperature. Figure 6 shows that moisture treatments when adding water from 0 to more than $50 \mathrm{~g}$ (in $150 \mathrm{~g}$ soil) describe, generally, a direct relationship between the amount of water and temperature. However, between 25 to $50 \mathrm{~g}$ of water and for temperatures lower than $15^{\circ} \mathrm{C}, \mathrm{CO}_{2}$ 
production seems to be constant, pointing to a possible $\mathrm{CO}_{2}$ dissolution in the soil water, enhanced at lower temperatures.

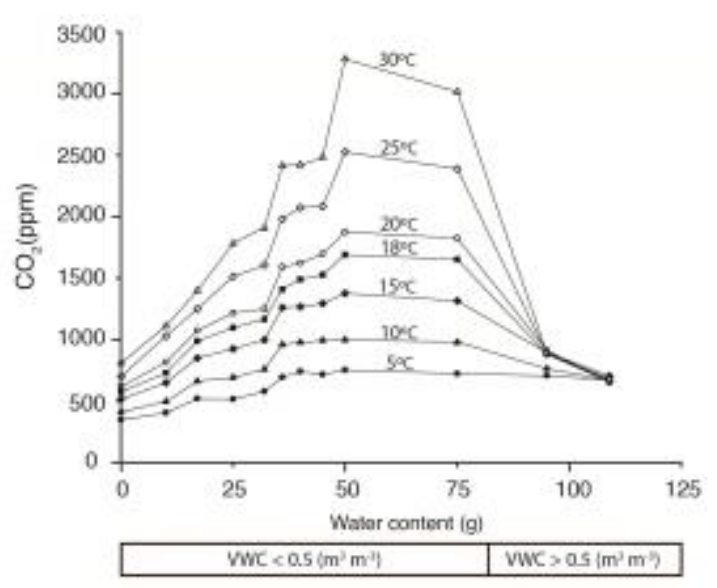

Figure 6. $\mathrm{CO}_{2}$ concentration in soil for the different moisture contents and temperatures.

Major $\mathrm{CO}_{2}$ concentrations are related to maximum temperatures and higher water contents in soil. In contrast, an opposite pattern is described by the soil samples with permanent high water contents (related to VWC larger than $0.5 \mathrm{~m}^{3} \mathrm{~m}^{-3}$ ). In this group, soil samples are related to lower and almost constant soil productions, describing a negative linear relationship between this parameter and the $\mathrm{CO}_{2}$ concentration.

From this experiment, $\mathrm{CO}_{2}$ concentration was parameterized via a logarithmic expression of soil temperature and volumetric water content for samples containing less than $50 \mathrm{~g}$ of water (VWC $<0.5 \mathrm{~m}^{3}$ $\left.\mathrm{m}^{-3}\right)$.

$\log \mathrm{CO}_{2}=(1.78 \cdot \mathrm{VWC}+2.52)+(0.05 \cdot \mathrm{VWC}+0.02) \cdot \mathrm{T}_{\text {soil }}$

The goodness of the fitting was $R^{2}=0.9366$. This reliability was lower when applying the model to monthly field data (Rull soil temperature and VWC as inputs) to compare measured and estimated soil concentrations because it underestimated soil $\mathrm{CO}_{2}$ in an average of $27 \%$.

\section{Discussion}

\subsection{Gaseous recharge of Rull cave}

Rull cave is a karstic cavity which might be representative of a wide range of natural shallow vadose environments. The analysis of this particular case pretend to summarize the complex relationships 
between the outdoor atmosphere, the soil/rock membrane and the underground atmosphere, which conform a multicomponent system (Figure 7).

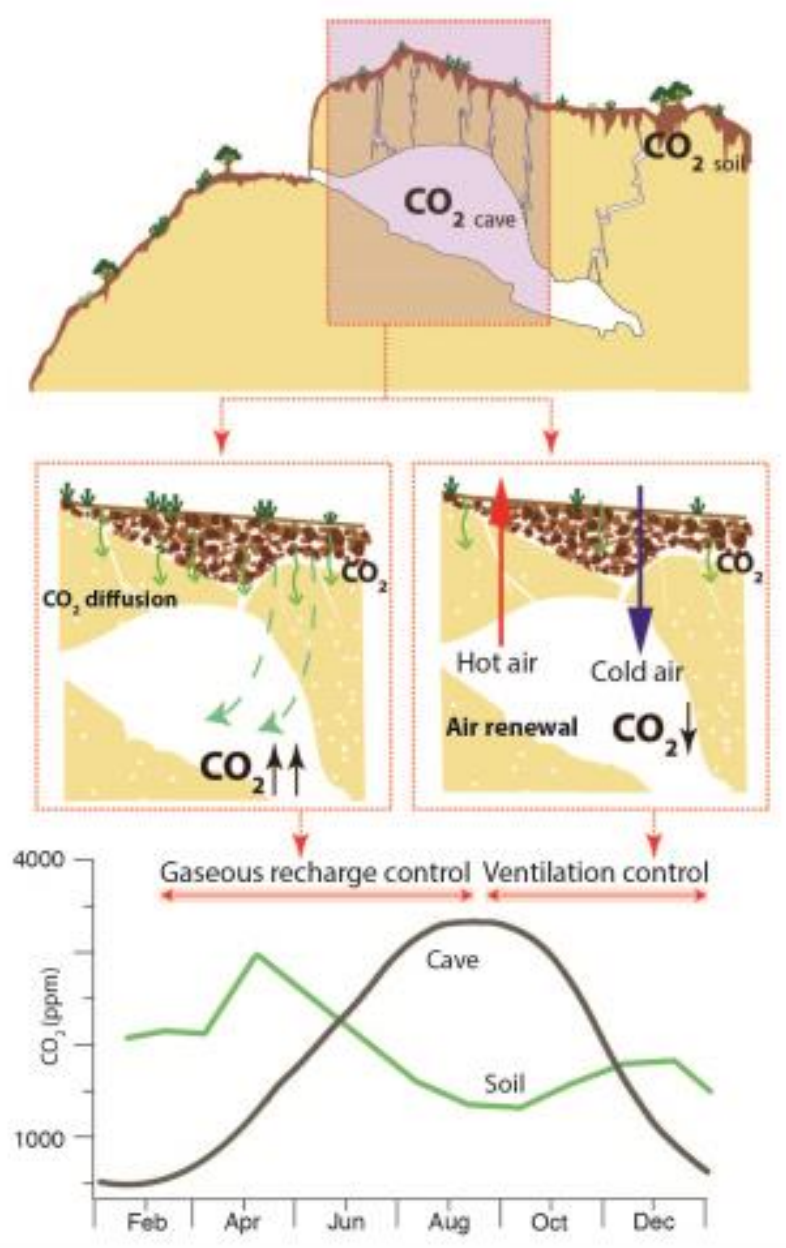

Figure 7. Seasonal dependence between the outdoor atmosphere, the soil/rock membrane and the underground atmosphere.

As Figure 2 shows, Rull cave experiences annually periodic cycles. Both gases, ${ }^{222} \mathrm{Rn}$ and $\mathrm{CO}_{2}$ follow the same pattern even when the source is different. These annual cycles are characterized by two outstanding moments related with the thermal relationship between outdoor and indoor air temperatures and responsible for the intensity of cave ventilation (Bourges et al., 2006; Frisia et al., 2011; Breecker et al., 2012). The cave is governed by a dynamic model, which combines diffusive and adevctive fluxes. Although both exist simultaneously the prevalence of one process over another for a certain period is responsible for the gaseous concentration in the cavity. Every year, between March and May, $\mathrm{T}_{\text {out }}$ exceeds $\mathrm{T}_{\text {in }}$ and density difference between both air masses derives in a pause on the 
ventilation prevalence. As consequence, the colder and denser air in the cavity remains nearly stagnated and the existing advective gaseous movement between exterior and interior air masses becomes lower. The connexion between cave and atmosphere becomes limited. This makes possible that ${ }^{222} \mathrm{Rn}$ concentration, emitted by soil and rock, increases constantly in the cavity. This state also allows that a direct diffusion of $\mathrm{CO}_{2}$ soil derived to the cavity (Faimon et al., 2012) prevails for a certain period being of a great significance. Lighter $\delta^{13} \mathrm{CO}_{2}$ values indicate periods dominated by soil $\mathrm{CO}_{2}$ production. Thus, the lighter values of $\delta^{13} \mathrm{CO}_{2}$ within the cave from the beginning of the isolation stage (Figure 3(b)) might confirm a direct contribution of soil $\mathrm{CO}_{2}$. Moreover, the existence of a $\mathrm{CO}_{2}$ concentration gradient between the soil and the cave confirms the possibility of the $\mathrm{CO}_{2}$ diffusion from soil (Figure 2). Major concentrations of soil $\mathrm{CO}_{2}$ are found for the two cycles between March and May, which would stimulate the beginning of the diffusion considering cave $\mathrm{CO}_{2}$ concentration. By diffusion, soil $\mathrm{CO}_{2}$ reaches the cavity and provokes its gaseous recharge. During this stage the cavity acts as a sink of $\mathrm{CO}_{2}$. In July and August, when the cave $\mathrm{CO}_{2}$ levels exceed soil $\mathrm{CO}_{2}$ concentration, $\mathrm{CO}_{2}$ concentration climbs to maximums. Soil, epikarst and cave are continuously communicated. Soil-produced $\mathrm{CO}_{2}$ slowly downwards to the cave filling the pore space of the rock. Therefore, the epikarst also presents a high $\mathrm{CO}_{2}$ concentration. During the dry and warm season soil-contained $\mathrm{CO}_{2}$ decreases due to the less production and higher communication with the exterior atmosphere. This slowly affects the epikarst and lately would affect the cave. However, the decrease of $\mathrm{CO}_{2}$ in the cave is lagged to the decrease of $\mathrm{CO}_{2}$ in the soil because the epikarst (which, at this period, presents a high concentration of $\mathrm{CO}_{2}$ ) damps the soil-cave relationship (in Rull cave the relative thickness of the host rock varies from 9 to 23 metres). The epikarst acts as the source while its $\mathrm{CO}_{2}$ level remains higher than the cave.

\subsection{Diffusive transport of soil-produced $\mathrm{CO}_{2}$ to the underground}

The average length of the recharge for these 3 years was 155 days. $\mathrm{CO}_{2}$ concentration in soil increases with depth (Amundson et al., 1998; Amundson, 2001; Fierer et al., 2005) and thus the measured soil $\mathrm{CO}_{2}$ values (Figure 2) are likely higher at the bottom of the soil profile (i.e. the existing soil-cave concentration gradient will be higher). The $\mathrm{CO}_{2}$ concentration gradient, the diffusion coefficient and the depth by which the gas moves trough determine the existence of a diffusive flux as described by Fick's Law. For Rull soil, $\mathrm{CO}_{2}$ diffusion coefficient obtained from lab measures in dry soil was $1.49 \cdot 10^{-6} \mathrm{~m}^{2} \mathrm{~s}^{-1}$ 
and this value was reduced to $0.61 \cdot 10^{-6} \mathrm{~m}^{2} \mathrm{~s}^{-1}$ when the soil was saturated with $0.30 \mathrm{~m}^{3} \mathrm{~m}^{-3}$ (Pla et al., 2016b). Soil column tests demonstrated the narrow relation between $\mathrm{CO}_{2}$ diffusion and water content in soil, which also depends on temperature variations. A rise in the soil water content produces the closure of the soil pore system, which hinders gas circulation and, consequently, the diffusive transport is slower.

On the one side, the diffusion predominance in the cave is triggered once the gradient of temperatures $\left(T_{\text {out }}-T_{\text {in }}\right)$ is inverted. On the other, the maximum $\mathrm{CO}_{2}$ stored volume within the cavity is consequence of the soil $\mathrm{CO}_{2}$ concentration that lately depends on soil temperature and moisture as demonstrated by the incubation experiment.

Soil-produced $\mathrm{CO}_{2}$ diffuses towards the less concentrated underground environment, filling the cracks, voids and porous system, reaches the cave and increases the $\mathrm{CO}_{2}$ concentration of the inner environment. Diffusion mechanism will be equally regulated by the available air-filled pore space within the host rock (primary and secondary porosity), which will allow the gas diffusive transport from the soil to the cave.

\subsection{Temporally pattern of $\mathrm{CO}_{2}$ concentration in soil}

$24 \mathrm{~h}$ sampling revealed significant relationships between soil temperature and $\mathrm{CO}_{2}$ fluxes from soil to atmosphere and concentration in soil air (Figure 4). The $24 \mathrm{~h}$ field campaign was performed in summer when the senescent nature of the vegetation in this period reduces the autotrophic component of soil respiration. The results from the $24 \mathrm{~h}$ monitoring campaign show that soil temperature is the parameter that mainly controls the evolution of soil $\mathrm{CO}_{2}$, and so that, the existing relationship between temperature and $\mathrm{CO}_{2}$ concentration in the laboratory experiment is supported, even considering the scarce water content in soil. The water content does not seem to play a definitive role in the daily cycle. Among other factors, the fall in soil temperature at night is enough to decrease soil $\mathrm{CO}_{2}$ as demonstrated by the laboratory experiments. But, in addition, at night, rises in relative humidity might cause water to condensate in the soil pore space and once saturated with water, it can be virtually impermeable to gas movement. Furthermore, within the $24 \mathrm{~h}$ field campaign, at night, relative humidity in the atmosphere increases, temperature decreases and water content in soil increases. In Figure 4 the increase in $\delta^{13} \mathrm{CO}_{2}$ at night (from $-19 \%$ to $-16 \%$ ) is caused by the colder and denser external air which 
enters the soil by an advective mechanism. Under this situation, the external air produces that $\delta^{13} \mathrm{CO}_{2}$ becomes heavier and reduces $\mathrm{CO}_{2}$ fluxes and $\mathrm{CO}_{2}$ soil concentration. Although it has not been quantified in this study, the occurrence of abiotic processes might contribute, in addition, to variations in $\mathrm{soil}^{\mathrm{CO}_{2}}$ (Emmerich, 2003). Particularly, associated to geochemical reactions occurring due to the $\mathrm{CO}_{2}$ interchange between air, water and the host rock. Soil $\mathrm{CO}_{2}$ would react with the carbonate host rock of the cavity. The highest temperatures and the driest situation during summer (within the $24 \mathrm{~h}$ field campaign) would reinforce the precipitation of carbonate, contributing to changes in the $\delta^{13} \mathrm{CO}_{2}$.

Soil temperature is a decisive factor and many researchers use soil temperature as the main environmental driven in soil respiration (Raich and Schlesinger, 1992; Kätterer et al., 1998; Mukhortova et al., 2015). However, in semiarid regions moisture has been demonstrated to be a major factor driving soil respiration (Lavigne et al., 2004; Badia et al., 2013; Chang et al., 2014). The annual sampling reveals that higher temperatures correspond to the lowest soil $\mathrm{CO}_{2}$ concentrations, and, therefore the direct relationship between soil temperature and soil $\mathrm{CO}_{2}$ becomes weaker in the larger time scales. Nevertheless, the soil water content seems to be substantial in the annual periods. The lack of water in soil is decisive when soil $\mathrm{CO}_{2}$ drops to minimums every year in summer. In addition, this lowest VWC favours a soil porous system with no water, responsible for a major soil ventilation (atmospheric air easily mixes with the soil air). Both, the scarce VWC and the soil ventilation, are responsible for the decreases in soil $\mathrm{CO}_{2}$ concentration and for the heavier $\delta^{13} \mathrm{CO}_{2}$ values in the warmer months. Soil VWC is responsible for differences in soil $\mathrm{CO}_{2}$ concentration in 2014 and 2015. In 2014, rainfall previous to the beginning of the diffusion recharge (January-May) was $81 \mathrm{~mm}$ and in 2015 for the same period it was $284 \mathrm{~mm}$. The major rainfalls resulted in a major soil $\mathrm{CO}_{2}$ concentration. This major $\mathrm{CO}_{2}$ soil production derived in a higher cave $\mathrm{CO}_{2}$ concentration, which diffused from soil. While maximum value of $\mathrm{cave}^{\mathrm{CO}} \mathrm{C}_{2}$ was 3169 ppm in 2014 it raised up to 3659 in 2015 (Figure 2). So that, the slope of the recharge period varies in each cycle depending on the existing relationships between soil and cave (Table 2 and Figure 2). Although there is evidence of a constant slope for the whole recharge, the curve tends to show a faster rate at the beginning of the process. The largest measured concentration gradient between soil and cave appeared in 2015, coincident with the shortest recharge.

Vargas et al. (2010b) demonstrated that relationships between soil moisture and soil production were significant at intermediate periods while strong significant correlations were observed between soil 
production and soil temperature at the 1-day period. VWC in soil seems to be decisive when rising soil $\mathrm{CO}_{2}$ concentration. In Rull soil, as in many semiarid locations, soil moisture strongly influences the physiological activity of vegetation and soil microbes ( $Q i$ and $X u, 2001$ ) and thus the driest periods show the minor soil $\mathrm{CO}_{2}$ concentrations. Specially during the dry season and considering these semiarid environments, rain events cause a notable increase in the soil respiration (Xu et al., 2004; Chen et al., 2014). Xu et al. (2004) confirmed that during dry seasons soil microbes respond quickly to a sudden increase in soil moisture from occasional rain events, and this is the cause of the great and anomalous increase in soil $\mathrm{CO}_{2}$ that took place in November 2015. Relative to this, Zornoza et al. (2016) affirmed that intense precipitation events provoke soil saturation by water, which leads to decreases in soil respiration rates. This could be due to a decrease in soil $\mathrm{CO}_{2}$ diffusivity or soil $\mathrm{CO}_{2}$ production. In our laboratory experiment, the dependence between water content and temperature with soil-produced $\mathrm{CO}_{2}$ was demonstrated. In addition, the detected $\mathrm{CO}_{2}$ decrease in samples with highest VWC might be related to the decrease in soil $\mathrm{CO}_{2}$ production due to the soil complete saturation by water (Figure 6). In Rull site, the effect of the rainfall events in soil water content was punctual due to the scarce occurrence of them and, when occur, due to rapid infiltration. Contrary to the incubation experiments, registered rainfalls did not cause the water saturation of soil, which would have been related to descents in soil $\mathrm{CO}_{2}$. Maximum value of field VWC (related to unusual occasions) was $0.53 \mathrm{~m}^{3} \mathrm{~m}^{-3}$ and thus such as high water contents $\left(>0.5 \mathrm{~m}^{3} \mathrm{~m}^{-3}\right)$ were not found frequently and permanently in the field measurements.

\subsection{Gaseous discharge of Rull cave}

When $\mathrm{CO}_{2}$ from soil and cave air gets balanced the gradient between concentrations becomes inexistent and diffusion process finalizes (July-August). As aforementioned, soil $\mathrm{CO}_{2}$ values (Figure 2), should be larger if the measure was performed at a higher depth and thus the gradient between soil and cave would get balanced later. Most of the $\mathrm{CO}_{2}$ interchange occurs between the deepest part of soil-epikarst and the cave. When the concentration gradient reverses sign, an opposite diffusion $\mathrm{CO}_{2}$ flux would start from the cave to the soil. After reaching the maximum, cave air $\mathrm{CO}_{2}$ concentration starts decreasing even when $\mathrm{T}_{\text {out }}$ is still higher than $\mathrm{T}_{\text {in }}$. This weak decrease in cave air $\mathrm{CO}_{2}$ could be related to the air movement to the deepest parts of the cave due to either a concentration gradient or a thermal stratification of the air mass inside the cave. 
The sharp decrease in cave air $\mathrm{CO}_{2}$ occurs when ventilation starts. The thermal inversion between outdoor and indoor temperatures changes the gaseous dynamics in the cavity. Rull cave volume is lower in elevation than the entrance, and this factor is decisive for the ventilation of the cavity. Every year between October and November, cave air temperature is higher than the outdoor temperature and, under this situation, ventilation becomes efficient through host rock fractures because the denser outside air flows into the cave, mixing with and displacing the $\mathrm{CO}_{2}$-rich cave air, and causing $\mathrm{CO}_{2}$ levels within the cave to decrease.

A similar seasonal pattern of the composition of cave atmosphere and its gas exchange with exterior has been previously study by James et al. (2015). The process is also confirmed by the ${ }^{222} \mathrm{Rn}$ concentration, a good indicator of the connexion between the subterranean environment and the atmosphere (Valladares et al., 2014), which, simultaneously to the $\mathrm{CO}_{2}$, suffers a sharp decrease as consequence of the ventilation.

The input of atmospheric air into the cavity produces a heavier $\delta^{13} \mathrm{CO}_{2}$ within the cave, as showed in Figure 3. The period needed to replace the cave air $\left(\mathrm{CO}_{2}\right.$ enriched) by ventilation (advection process) is shortest in comparison with the diffusive recharge (Table 2). Although lowest cave $\mathrm{CO}_{2}$ concentration is reached between February and March, the most pronounced descent in cave takes place in a short time lapse that ends between November and December.

\subsection{The role of Rull cave in the soil-produced $\mathrm{CO}_{2}$ redistribution. Considerations on climate change}

While Rull cave remains ventilated, continuous air exchange dominates the underground atmosphere and although $\mathrm{CO}_{2}$ diffusion from soil to cave exists for the most part of the ventilation period (as demonstrated by the variation of the $\delta^{13} \mathrm{CO}_{2}$ cave measures) it is hindered by a strong external and continuous air supply. The ventilation stage implies that the cavity acts as a $\mathrm{CO}_{2}$ source. Plenty of $\mathrm{CO}_{2}$ is contained in the subterranean environments, turning these environments into non-negligible contributors in the global $\mathrm{CO}_{2}$ balance, which should not be underestimated (Serrano-Ortiz et al., 2010; Cuezva et al., 2011; Bourges et al., 2014). Caves redistribute the soil-produced $\mathrm{CO}_{2}$. Their stored $\mathrm{CO}_{2}$ capacity and potential contribution to the annual global $\mathrm{CO}_{2}$ cycle will be different depending on the climatic relationships and soil properties for each site. A mass balance in terms of air advection (ventilation) between the Rull cave and the outside atmosphere estimates the total $\mathrm{CO}_{2}$ flux from the 
cave to the external atmosphere for all the studied cycles. The model was previously established in Garcia-Anton et al. (2014) and Fernandez-Cortes et al. (2015b), which developed a method for calculating the mass balance of $\mathrm{CO}_{2}$ in dynamically ventilated caves.

Air movement that produces the inflow of exterior air primarily controls the $\mathrm{CO}_{2}$ outgassing of the cave air. Therefore, in the ventilation stage, the cave air is the resulting air mixture of the initial subterranean atmosphere $\left(\mathrm{CO}_{2}\right.$-background before the process) and a certain quantity of the exterior air input that enters the cavity due to a volumetric air exchange.

Considering any volumetric unit (relative volume), the total cave air volume $\left(V_{c}\right)$, the total volume of background component $\left(\mathrm{V}_{\mathrm{b}}\right)$ and the total volume of exterior air input into the cave $\left(\mathrm{V}_{\mathrm{e}}\right)$ are related as follows:

$V_{c}=V_{b}+V_{e}=1$

By means of a mass balance, the concentration of the cave air can be written as a relation between the background component $\left(\mathrm{V}_{\mathrm{b}}\right)$ and the exterior component $\left(\mathrm{V}_{\mathrm{e}}\right)$ :

$\left[\mathrm{CO}_{2}\right]_{\mathrm{c}} \cdot \mathrm{V}_{\mathrm{c}}=\left[\mathrm{CO}_{2}\right]_{\mathrm{b}} \cdot \mathrm{V}_{\mathrm{b}} \times\left[\mathrm{CO}_{2}\right]_{\mathrm{e}} \cdot \mathrm{V}_{\mathrm{e}}$

Or in a time-dependent relation:

$\left[\mathrm{CO}_{2}\right]_{\mathrm{c}}(\mathrm{t})=\left[\mathrm{CO}_{2}\right]_{\mathrm{b}}+\mathrm{V}_{\mathrm{e}}(\mathrm{t}) \times\left(\left[\mathrm{CO}_{2}\right]_{\mathrm{e}}-\left[\mathrm{CO}_{2}\right]_{\mathrm{b}}\right)$

where $\left[\mathrm{CO}_{2}\right]_{c}(\mathrm{t})$ is the $\mathrm{CO}_{2}$ cave concentration $(\mathrm{ppm})$ in the end of the ventilation slope (NovemberDecember), considering the period taken for the emptying of the cavity and which varies from cycle to cycle. $\left[\mathrm{CO}_{2}\right]_{\mathrm{b}}$ is the background concentration of $\mathrm{CO}_{2}(\mathrm{ppm})$ inside the cave at the beginning of the ventilation period, $\left[\mathrm{CO}_{2}\right]_{\mathrm{e}}$ is the average $\mathrm{CO}_{2}$ concentration in the exterior atmosphere (average value for the studied period of $423 \mathrm{ppm}$ ) and $V_{e}(t)$ is the total volume of exterior air input into the cave, dependent on the time or, in other words, the ventilation rate between the exterior and the cave.

The length of the gaseous ventilation for each annual cycle was 94 and 114 days for 2013 and 2014 (Table 2 and Figure 2). For the last cycle (2015-2016), the last data was acquired in January 12 (2016), when minimum had not yet been reached. Thus, the length would be larger than 110 days. The calculated volume for Rull cave is $9915 \mathrm{~m}^{3}$ and thus, the net amount of $\mathrm{CO}_{2}$ (considering the total discharge period) emitted to the atmosphere was 62 and $55 \mathrm{~kg}$ for 2013 and 2014. A total amount of 55 $\mathrm{kg}$ was also calculated for the last cycle, but the amount of $\mathrm{CO}_{2}$ would be larger since in January 12 (2016) the lowest $\mathrm{CO}_{2}$ cave concentration was not reached. The estimations for other subterranean 
galleries reveal significant estimated outgassing daily fluxes of $\mathrm{CO}_{2}$ with different order of magnitude (e.g. $120 \mathrm{~mol}^{-1} \mathrm{day}^{-1}$ on average for the Hollow Ride cave (Kowalczk and Froelich, 2010), 2.34 to $11.71 \mathrm{~kg}$ day $^{-1}$ for Grotta di Ernesto (Frisia et al., 2011) or $335 \mathrm{~kg}^{\text {day }}{ }^{-1}$ for Ojo Guareña karst system (FernandezCortes et al., 2015b)).

The distribution of continental outcrops of karst rocks, mainly carbonates and evaporites, ranges 13.8 $16.7 \cdot 10^{6} \mathrm{~km}^{2}$ and $0.16 \cdot 10^{6} \mathrm{~km}^{2}$, respectively, according to some surficial Earth system analyses (Suchet et al., 2003; Durr et al., 2005; Ford and Williams, 2007). Other previous studies estimate the karst landforms cover $10-20 \%$ of the continental surface (Palmer, 1991). Most of karst landscapes exhibit solution-enlarged fractures, caves, and internal drainage networks that provide conduits for the advective flow of air though porous rock units and, consequently, it causes large volumes of the atmosphere to interact with subterranean surface areas.

The worldwide surface area of the conduits capable of interacting with the atmosphere is unknown but, as a first attempt, we have extrapolated the locus pattern of $\mathrm{CO}_{2}$ sink/source of Rull cave to a global scale, according to the upscaling steps provided by Fernandez-Cortes et al., (2015b). The monitoring study at Rull cave has provided the following key parameters needed for this upscaling procedures, including: i) number of day per year with high ventilation (106 days), ii) averaged mass of $\mathrm{CO}_{2}$ evacuated during the annual season of cave air ventilation from 2013 to 2015 (57 Kg) and iii) depth of karstified vadose zone where air exchange with exterior by advective process is noticeable in accordance to our cave monitoring results $(23 \mathrm{~m})$. From this parameterization, we also estimate that the amount of subsurface-related $\mathrm{CO}_{2}$ evacuated by advective forces likely ranges 33.7-44.0 $\mathrm{Tg}_{\text {year }}^{-1}$ on a global scale. The result of the evacuated $\mathrm{CO}_{2}$ mass seems to be underestimated in comparison with other studies (Serrano-Ortiz et al., 2010; Fernandez-Cortes et al., 2015b) as consequence of the small dimensions of Rull cave compared to other longer subterranean systems.

It has been previously demonstrated that, among other factors, the main drivers in establishing when a subterranean environment acts as a sink or source of $\mathrm{CO}_{2}$ are the existing climatic parameters. In Rull cave, results confirm the narrow existing dependence between climate conditions and $\mathrm{CO}_{2}$ dynamics in the cave-soil-atmosphere system. Variations in outdoor temperature directly affect, on the one side, to the beginning/ending of the diffusion recharge and to the ventilation (discharge) of the cavity. Besides, rises in outdoor temperature cause rises in cave temperature, which becomes higher every year. On the 
other side, variations in outdoor temperature directly affect to soil. Soil parameters are essential in soil production and thus, in the amount of soil derived $\mathrm{CO}_{2}$. In addition, rainfall influences all the process in annual scales. As seen above, in this semiarid region, major rainfalls will be responsible for major soil productions. And as established previously by other authors (Tang et al., 2003; Turcu et al., 2005; Jabro et al., 2012) the gaseous diffusion through soil will vary in accordance to the water content in soil.

Climatic variations regulate the gaseous cycles of the cavity and shape them. Future predictions about climatic change in long time scales may consider all these changes in order to better estimate future scenarios of these natural $\mathrm{CO}_{2}$ temporary reservoirs that suppose large amounts of this greenhouse gas to the lower troposphere (Benavente et al., 2015), accordingly to the annual soil-produced $\mathrm{CO}_{2}$ redistribution. When considering future occurrences, the Coupled Model Intercomparison Project Phase 5 (CMIP5) shows a general tendency for annual-mean conditions to be warmer and drier, which is confirmed at the geographical coordinates of the cave surface. For instance, it predicts that extreme precipitation generally increases faster than total wet-day precipitation. In regions such as the Mediterranean, increases in consecutive dry days coincide with decreases in heavy precipitation days and maximum consecutive 5-day precipitation, which indicates future intensification of dry conditions (Sillmann et al., 2013). This is coincident with the Mediterranean climate expectation about the reduction in the intensity and distribution of rainfalls (IPCC, 2013; Matteucci et al., 2015; among others). Furthermore, other climate change scenarios predict a global trend towards increasing extremes in precipitation without changing the total precipitation (Xu et al., 2004), which will contribute to the erratic seasonal and inter-annual distribution of precipitation events. ALADIN climate model simulations, focused on the Mediterranean area and provided by the MED-CORDEX initiative (Herrmann et al., 2011; Tramblay et al., 2013; www.medcordex.eu, Ruti et al., 2015), confirm the warmer and drier trends in Rull area. Taking into consideration the estimated values from applying the ALADIN simulations to Rull site and considering Eq. (1), reductions in soil VWC, will be responsible for decreases in soil $\mathrm{CO}_{2}$. Future under this situation will derive in changes in the $\mathrm{CO}_{2}$ storage capacity of the cavity.

Changes in the stored $\mathrm{CO}_{2}$ concentration along the annual cycle in Rull cave might not mean a significant change in the contribution of $\mathrm{CO}_{2}$ to the global carbon cycle but, considering the multiple potential hotspots in regions with subterranean atmospheres, it is timely to consider these terrestrial ecosystems in future estimates for carbon balance and, in particular, its key role as $\mathrm{CO}_{2}$ regulators under the 
upcoming climatic scenarios.

\section{Conclusions}

This study relies on the existing relationships in the multicomponent system conformed by the outdoor atmosphere, the soil/rock membrane and the underground atmosphere. Within the cave, the gaseous recharge primarily occurs when $\mathrm{CO}_{2}$ diffusion from soil prevails to advective gaseous movement. This state favours the effect of soil $\mathrm{CO}_{2}$ diffusion responsible for substantial increases in cave $\mathrm{CO}_{2}$ concentration. Maximum values of soil $\mathrm{CO}_{2}$ are coincident with the beginning of the cave gaseous recharge and, as consequence, the diffusion process is enhanced due to the significant gradient of $\mathrm{CO}_{2}$ concentration between soil and cave air. Although diffusion is responsible for the gaseous recharge of the cavity, in some cases, additional direct advective fluxes from soil (containing $\mathrm{CO}_{2}$ enriched air) could occur simultaneously to the diffusion recharge. Soil $\mathrm{CO}_{2}$ diffusion is also strongly linked to the soil pore space, which is responsible for the gas movement depending on the water saturation. Soil temperature and moisture directly influence soil $\mathrm{CO}_{2}$ production although different patterns have been found related to the time scale. While daily $\mathrm{CO}_{2}$ soil cycles are mainly controlled by soil temperature, in the larger $\mathrm{CO}_{2}$ time scales, the direct relationship between soil temperature and soil $\mathrm{CO}_{2}$ disappear. Moisture content is substantial in the annual periods as the lack of water in soil is decisive when soil $\mathrm{CO}_{2}$ drops to minimums. Not only the length but also the slope of the recharge period in each annual cycle vary depending on soil and cave, and so does the amount of stored $\mathrm{CO}_{2}$ in the cave. The final of the diffusion recharge is conditioned for the balance in soil-cave concentrations and the vanishing of the concentration gradient.

The ventilation state, characterized by continuous air interchange between the underground and the outdoor atmosphere, is consequence of the thermal inversion between temperatures. During this state, the effect of soil $\mathrm{CO}_{2}$ diffusion on the $\mathrm{CO}_{2}$ in underground air is hindered by a strong external and continuous air supply which implies that the cavity acts as a $\mathrm{CO}_{2}$ source. Caves participate in the soilproduced $\mathrm{CO}_{2}$ redistribution throughout an annual cycle. Depending on the climatic relationships and soil properties for each cycle, the $\mathrm{CO}_{2}$ contribution to the atmosphere by ventilation is different. Among other factors, the main drivers in establishing when a subterranean environment acts as a sink or source of $\mathrm{CO}_{2}$ are the existing climatic parameters. As it has been demonstrated, climatic variations regulate 
the gaseous cycles of the cavity and shape them. Future climate predictions highlight a general tendency for annual-mean conditions to be warmer and drier, also confirmed for Rull site. Under this situation, soil $\mathrm{CO}_{2}$ production will be driven by increased temperatures and scarce water content. At global level, forecasting about climatic change in long time scales may consider all these changes in order to better estimate upcoming scenarios of natural $\mathrm{CO}_{2}$ source that suppose large amounts of this greenhouse gas to the lower troposphere.

\section{Acknowledgements}

This research was funded by the Spanish Ministry of Economy and Competitiveness projects CGL201125162 and CGL2013-43324-R and its programme Torres Quevedo (PTQ 13-06296 and PTQ 12-05601). A pre-doctoral research fellowship (BES-2012-053468) was awarded to C. Pla for the project CGL201125162. Funding was also provided by the People Programme (Marie Curie Actions-Intra-European Fellowships, call 2013) of the European Union's Seventh Framework Programme (FP7/2007-2013) under the REA grant agreement n624204. The authors thank cave managers for their collaboration throughout the entire investigation. We thank the authors of the ALADIN simulations used in the current work and downloaded from the Med-CORDEX database (www.medcordex.eu). We also thank to F. Tárraga and all the members of the UA electronic lab and J.M. Martínez for their valuable technical support.

\section{$\underline{\text { References }}$}

Amundson, R., Stern, L., Baisden, T., Wang, Y., 1998. The isotopic composition of soil and soil-respired $\mathrm{CO}_{2}$. Geoderma, 82(1-3): 83-114. Doi: 10.1016/S0016-7061(97)00098-0

Amundson, R., 2001. The carbon budget in soils. Annual Review of Earth and Planetary Sciences, 29:535562. Doi: 10.1146/annurev.earth.29.1.535

Badia, D., Marti, C., Aguirre, A.J., 2013. Straw management effects on $\mathrm{CO}_{2}$ efflux and $\mathrm{C}$ storage in different

Mediterranean agricultural soils. Science of the Total Environment, 465:233-239. Doi: 10.1016/j.scitotenv.2013.04.006

Benavente, J., Vadillo, I., Liñan, C., Carrasco, F., Soler, A., 2011. Ventilation effects in a karstic show cave and in its vadose environment, Nerja, Southern Spain. Carbonates and Evaporites 26(1):11-17. Doi: $10.1007 / \mathrm{s} 13146-011-0050-9$ 
Benavente, D., Pla, C., Grossi, C., Garcia-Anton, E., Cuezva, S., Fernandez-Cortes, A., Sanchez-Moral, S., Cañaveras, J.C., 2015. Evolution of $\mathrm{CO}_{2}$ storage in karstic cavities by changes in climate in semiarid regions: Rull Cave (Alicante, Spain). International Scientific Conference: Our common future under climate change, 7-10 July 2015, Paris.

Bourges, F., Mangin, A., d'Hulst, D., 2001. Carbon dioxide in karst cavity atmosphere dynamics: the example of the Aven d'Orgnac (Ardeche). Comptes Rendus De I'Academie des Sciences Serie IIA Earth and Planetary Science, 333(11):685-692. Doi: 10.1016/s1251-8050(01)01682-2

Bourges, F., Genthon, P., Mangin, A., D'Hulst, D., 2006. Microclimates of I'Aven d'Orgnac and other French limestone caves (Chauvet, Esparros, Marsoulas). International Journal of Climatology, 26(12):1651-1670. Doi: 10.1002/joc.1327

Bourges, F., Genthon, P., Genty, D., Lorblanchet, M., Mauduit, E., D'Hulst, D., 2014. Conservation of prehistoric caves and stability of their inner climate: Lessons from Chauvet and other French caves. Science of the Total Environment, 493(0):79-91. Doi: 10.1016/j.scitotenv.2014.05.137

Breecker, D.O., Payne, A.E., Quade, J., Banner, J.L., Ball, C.E., Meyer, K.W., Cowan, B.D., 2012. The sources and sinks of $\mathrm{CO}_{2}$ in caves under mixed woodland and grassland vegetation. Geochimica and Cosmochimica Acta, 96:230-246. Doi: 10.1016/j.gca.2012.08.023

Chang, C.T., Sabate, S., Sperlich, D., Poblador, S., Sabater, F., Gracia, C., 2014. Does soil moisture overrule temperature dependence of soil respiration in Mediterranean riparian forests?. Biogeosciences, 11:6173-6185. Doi:10.5194/bg-11-6173-2014

Chen, S., Zou, J., Hu, Z., Chen, H., Lu, Y., 2014. Global annual soil respiration in relation to climate, soil properties and vegetation characteristics: Summary of available data. Agricultural and Forest Meteorology, 198:335-346. Doi: 10.1016/j.agrformet.2014.08.020

Crank, J., 1956. The mathematics of diffusion. London: Oxford University Press.

Crosson, E.R., 2008. A cavity ring-down analyzer for measuring atmospheric levels of methane, carbon dioxide, and water vapor. Applied Physics B Lasers and Optics, 92:403-408. Doi: 10.1007/s00340-0083135-y

Cuezva, S., Fernandez-Cortes, A., Benavente, D., Serrano-Ortiz, R., Kowalski, A.S., Sanchez-Moral, S., 2011. Short-term $\mathrm{CO}_{2}(\mathrm{~g})$ exchange between a shallow karstic cavity and the external atmosphere during 
summer: Role of the surface soil layer. Atmospheric Environment, 45(7):1418-1427. Doi: 10.1016/j.atmosenv.2010.12.023

Deines, P., 1980. The isotopic composition of reduced organic carbon. In: Fritz, P., Fontes, J.Ch. (Eds.)., Handbook of Environmental Isotope Geochemistry, Vol. 1. The Terrestrial Environment. Elsevier, Amsterdam, pp. 329-406.

Durr, H.H., Meybeck, M., Durr, S.H., 2005. Lithologic composition of the Earth's continental surfaces derived from a new digital map emphasizing riverine material transfer. Global Biogeochemistry Cycles, 19:4. Doi:10.1029/2005GB002515

Emmerich, W.E., 2003. Carbon dioxide fluxes in a semiarid environment with high carbonate soils. Agricultural and Forest Meteorology, 116(1-2):91-102. Doi: 10.1016/S0168-1923(02)00231-9

Faimon, J., Štelcl, J., Sas, D., 2006. Anthropogenic $\mathrm{CO}_{2}$-flux into cave atmosphere and its environmental impact: A case study in the Císařská Cave (Moravian Karst, Czech Republic). Science of the Total Environment, 369(1-3): 231-245. Doi: 10.1016/j.scitotenv.2006.04.006

Faimon, J., Ličbinská, M., Zajíček, P., 2012. Relationship between carbon dioxide in Balcarka Cave and adjacent soils in the Moravian Karst region of the Czech Republic. International Journal of Speleology, 41(1):17-28. Doi: 10.5038/1827-806X.41.1.3

Fang, J., Zhao, K., Liu, S., 1998. Factors affecting soil respiration in reference with temperature's role in the global scale. Chinese Geographical Science, 8(3):246-255. Doi: 10.1007/s11769-997-0018-9

Fernandez-Cortes, A., Sanchez-Moral, S., Cuezva, S., Benavente, D., Abella, R., 2011. Characterization of trace gases' fluctuations on a 'low energy' cave (Castañar de Íbor, Spain) using techniques of entropy of curves. International Journal of Climatology, 31(1):127-143. Doi: 10.1002/joc.2057

Fernandez-Cortes, A., Benavente, D., Cuezva, S., Cañaveras, J.C., Alvarez-Gallego, M., Garcia-Anton, E., Soler, V., Sanchez-Moral, S., 2013. Effect of water vapour condensation on the radon content in subsurface air in a hypogeal inactive-volcanic environment in Galdar cave, Spain. Atmospheric Environment 75(0): 15-23. Doi: 10.1016/j.atmosenv.2013.04.030

Fernandez-Cortes, A., Cuezva, S., Alvarez-Gallego, M., Garcia-Anton, E., Pla, C., Benavente, D., Jurado, V., Saiz-Jimenez, C., Sanchez-Moral, S., 2015a. Subterranean atmospheres may act as daily methane sinks. Nature communications, 6, Article no 7003. 
Fernandez-Cortes, A., Cuezva, S., Garcia-Anton, E., Alvarez-Gallego, M., Pla, C., Benavente, D., Cañaveras, J.C., Calaforra, J.M., Mattey, D.P., Sanchez-Moral, S., 2015b. Changes in the storage and sink of carbon dioxide in subsurface atmospheres controlled by climate-driven processes: the case of the Ojo Guareña karst system. Environmental Earth Science, 74:7715-7730. Doi: 10.1007/s12665-015-4710-2

Fierer, N., Chadwick, O.A., Trumbore, S.E., 2005. Production of $\mathrm{CO}_{2}$ in Soil Profiles of a California Annual Grassland, Ecosystems, 8:412-429. Doi: 10.1007/s10021-003-0151-y

Ford, D.C., Williams, P.W., 2007. Karst Hydrology and Geomorphology. Wiley, Chichester

Frisia, S., Fairchild, I.J., Fohlmeister, J., Miorandi, R., Spoetl, C., Borsato, A., 2011. Carbon mass-balance modelling and carbon isotope exchange processes in dynamic caves. Geochimica et Cosmochimica Acta, 75(2): 380-400. Doi: 10.1016/j.gca.2010.10.021

Galiana-Merino, J.J., Pla, C., Fernandez-Cortes, A., Cuezva, S., Ortiz, J., Benavente, B., 2014. EnvironmentalWaveletTool: Continuous and discrete wavelet analysis and filtering for environmental time series. Computer Physics Communications, 185(10):2758-2770. Doi: 10.1016/j.cpc.2014.06.011

Garcia-Anton, E., Cuezva, S., Fernandez-Cortes, A., Benavente, B., Sanchez-Moral, S., 2014. Main drivers of diffusive and advective processes of $\mathrm{CO}_{2}$-gas exchange between a shallow vadose zone and the atmosphere, International Journal of Greenhouse Gas Control, 21:113-129. Doi: 10.1016/j.ijggc.2013.12.006

Goffin, S., Aubinet, M., Maier, M., Plain, C., Schack-Kirchner, H., Longdoz, B., 2014. Characterization of the soil $\mathrm{CO}_{2}$ production and its carbon isotope composition in forest soil layers using the flux-gradient approach. Agricultural and Forest Meteorology, 188:45-57. Doi: 10.1016/j.agrformet.2013.11.005

Gombert, P., 2002. Role of karstic dissolution in global carbon cycle. Global and Planetary Change, 33(12):177-184. Doi:10.1016/S0921-8181(02)00069-3

Gulledge, J., Schimel, J.P., 2000. Controls on soil carbon dioxide and methane fluxes in a variety of taiga forest stands in interior Alaska. Ecosystems, 3:269-282. Doi: 10.1007/s100210000025

Herrmann, M., Somot, S., Calmanti, S., Dubois, C., and Sevault, F., 2011. Representation of spatial and temporal variability of daily wind speed and of intense wind events over the Mediterranean Sea using dynamical downscaling: impact of the regional climate model configuration. Natural Hazards and Earth System Sciences, 11:1983-2001. Doi:10.5194/nhess-11-1983-2011 
Houghton, R.A., Davidson, E.A., Woodwell, G.M., 1998. Missing sinks, feedbacks, and understanding the role of terrestrial ecosystems in the global carbon balance. Biogeochemical Cycles, 12:25-34. Doi: 10.1029/97GB02729

IPCC, 2013. Climate Change 2013: the Physical Science Basis. Contribution of Working Group I to the Fifth Assessment Report of the Intergovernmental Panel on Climate Change. Cambridge University Press, Cambridge, United Kingdom and New York, NY, USA, p. 1535.

Jabro, J.D. Sainju, U.M., Stevens, W.B., Evans, R. G., 2012. Estimation of $\mathrm{CO}_{2}$ diffusion coefficient at 0-10 cm depth in undisturbed and tilled soils. Archives of Agronomy and Soil Science, 58(1):1-9. Doi: $10.1080 / 03650340.2010 .506482$

James, E.W., Banner, J.L., Hardt, B., 2015. A global model for cave ventilation and seasonal bias in speleothem paleoclimate records. Geochemistry, Geophysics, Geosystems, 16:1044-1051. Doi: 10.1002/2014GC005658

Kätterer, T., Reichstein, M., Andren, O., Lomander, A., 1998. Temperature dependence of organic matter decomposition: a critical review using literature data analyzed with different models. Biology and Fertility of Soils, 27(3):258-262. Doi: 10.1007/s003740050430

Keeling, C.D., 1958. The concentration and isotopic abundances of atmospheric carbon dioxide in rural areas. Geochimica et Cosmochimica Acta, 13(4):322-334. Doi: 10.1016/0016-7037(58)90033-4

Kowalczk, A.J., Froelich, P.N., 2010. Cave air ventilation and $\mathrm{CO}_{2}$ outgassing by radon-222 modeling: How fast do caves breathe?. Earth and Planetary Science Letters, 289(1):209-219. Doi: 10.1016/j.epsl.2009.11.010

Kowalski, A.S., Sanchez-Cañete, E.P., 2010. A new definition of the virtual temperature, valid for the atmosphere and the $\mathrm{CO}_{2}$-rich air of the vadose zone. Journal of Applied Meteorology and Climatology, 49(8), 1692-1695. Doi: 10.1175/2010JAMC2534.1

Kuzyakov, Y., 2006. Sources of $\mathrm{CO}_{2}$ efflux from soil and review of partitioning methods. Soil Biology and Biochemistry, 38(3):425-448. Doi:10.1016/j.soilbio.2005.08.020

Lavigne, M.B., Foster, R.J., Goodine, G., 2004. Seasonal and annual changes in soil respiration in relation to soil temperature, water potential and trenching. Tree Physiology, 24:415-424. 
Liu, Z., Zhao, J., 2000. Contribution of carbonate rock weathering to the atmospheric $\mathrm{CO}_{2}$ sink. Environmental Geology, 39(9):1053-1058. Doi: 10.1007/s002549900072

Liu, Z., Dreybrodt, W., Wang, H., 2010. A new direction in effective accounting for the atmospheric $\mathrm{CO}_{2}$ budget: considering the combined action of carbonate dissolution, the global water cycle and photosynthetic uptake of DIC by aquatic organisms. Earth Science Reviews, 99:162-172. Doi: 10.1016/j.earscirev.2010.03.001

Liu, T., Xu, Z., Hou, Y., Zhou, G., 2016. Effects of warming and changing precipitation rates on soil respiration over two years in a desert steppe of northern China. Plant and Soil 400(1):15-27. Doi: $10.1007 / \mathrm{s} 11104-015-2705-0$

Martin, J.B., Brown, A., Ezell, J., 2013. Do carbonate karst terrains affect the global carbon cycle? Acta Carsologica, 42(2-3):187-196. Doi: 10.3986/ac.v42i2-3.660

Matteucci, M., Gruening, C., Goded-Ballarin, I., Seufert, G., Cescatti, A., 2015. Components, drivers and temporal dynamics of ecosystem respiration in a Mediterranean pine forest. Soil Biology and Biochemistry, 88:224-235. Doi: 10.1016/j.soilbio.2015.05.017

Mattey, D.P., Atkinson, T.C., Barker, J.A., Fisher, R., Latin, J.P., Durell, R., Ainsworth, M., 2016. Carbon dioxide, ground air and carbon cycling in Gibraltar karst. Geochimica et Cosmochimica Acta. In Press. Doi: 10.1016/j.gca.2016.01.041

Milanolo, S., Gabrovšek, F., 2015. Estimation of carbon dioxide flux degassing from percolating waters in a karst cave: Case study from Bijambare cave, Bosnia and Herzegovina. Chemie der Erde Geochemistry, 75(4):465-474. Doi: 10.1016/j.chemer.2015.10.004

Mukhortova, L., Schepaschenko, D., Shvidenko, A., McCallum, I., Kraxner, F., 2015. Soil contribution to carbon budget of Russian forests. Agricultural and Forest Meteorology, 200:97-108. Doi: 10.1016/j.agrformet.2014.09.017 
Nickerson, N., Risk, D., 2013. Using subsurface $\mathrm{CO}_{2}$ concentrations and isotopologues to identify $\mathrm{CO}_{2}$ seepage from CCS/CO2-EOR sites: A signal-to-noise based analysis. International Journal of Greenhouse Gas Control, 14:239-246. Doi: 10.1016/j.ijggc.2013.01.018.

O’Brien, K.E., Risk, D., Rainham, D., O’Beirne-Ryan, A.M., 2014. Using field analogue soil column experiments to quantify radon-222 gas migration and transport through soils and bedrock of Halifax, Nova Scotia, Canada. Environmental Earth Sciences, 72(7): 2607-2620. Doi: 10.1007/s12665-014-3168-y

Palmer, A.N, 1991. Origin and morphology of limestone caves. Geological Society of America Bulletin $103,1-21$.

Pla, C., Galiana-Merino, J.J., Cuevas-Gonzalez, J., Andreu, J.M., Cañaveras, J.C., Cuezva, S., FernandezCortes, A., Garcia-Anton, E., Sanchez-Moral, S., Benavente, D., 2015. Definition of Microclimatic Conditions in a Karst Cavity: Rull Cave (Alicante, Spain). In: Andreo, B., Carrasco, F., Duran J.J., Jimenez P., LaMoreaux J.W. (Eds.), Hydrogeological and Environmental Investigations in Karst Systems, Vol. 1. Springer Berlin Heidelberg, pp. 497-503. Doi: 10.1007/978-3-642-17435-3_56

Pla, C., Galiana-Merino, J.J., Cuezva, S., Fernandez-Cortes, A., Cañaveras, J.C., Benavente, D., $2016 a$. Assessment of $\mathrm{CO}_{2}$ dynamics in subsurface atmospheres using the wavelet approach: from cavityatmosphere exchange to anthropogenic impacts in Rull cave (Vall d'Ebo, Spain). Environmental Earth Sciences, 75(5):446. Doi: 10.1007/s12665-016-5325-y

Pla, C., Cuezva, S., Martinez-Martinez, J., Fernandez-Cortes, A., Garcia-Anton, E., Fusi, N., Crosta G.B., Cañaveras, J.C., Sanchez-Moral , S., Benavente, D., 2016b. Role of soil pore structure on water infiltration and $\mathrm{CO}_{2}$ exchange between atmosphere and underground air in vadose zone: a combined laboratory and field approach. Submitted to Catena.

Post, E.S., Grambsch, A., Weaver, C., Morefield, P., Huang, J., Leung, L.Y., Nolte, C.G., Adams, P., Liang, X.Z., Zhu, J.H., Mahoney, H., 2012. Variation in Estimated Ozone-Related Health Impacts of Climate Change due to Modeling Choices and Assumptions. Environmental Health Perspectives 120(11):15591564. Doi: $10.1289 /$ ehp.1104271

Qi, Y., Xu, M., 2001. Separating the effects of moisture and temperature on soil $\mathrm{CO}_{2}$ efflux in a coniferous forest in the Sierra Nevada Mountains. Plant Soil, 237(1):15- 23. Doi: 10.1023/A:1013368800287 
Raich, J.W., Schlesinger, W.H., 1992. The global carbon dioxide flux in soil respiration and its relationship to vegetation and climate. Tellus B, 44(2):81-99. Doi: 10.1034/j.1600-0889.1992.t01-100001.x

Ravbar, N., Kosutnik, J., 2013. Variations of karst underground air temperature induced by various factors (Cave of Zupanova jama, Central Slovenia). Theoretical and Applied Climatology, 116(1-2):327341. Doi: $10.1007 / \mathrm{s} 00704-013-0955-4$

Risk D., Kellman, L., 2008. Isotopic fractionation in non-equilibrium diffusive environments. Geophysical Research Letters, 35(2). Doi: 10.1029/2007GL032374

Rivas-Martinez, S., 1983. Pisos bioclimáticos de España. Lazaroa, 5: 33-44.

Rolston, D.E., Møldrup, P., 2002. Gas diffusivity. In: Dane, J.H., Topp, G.C., (Eds.) Methods of soil analysis. Part 4. SSSA Book Ser. 5, ASA and SSSA, Madison, WI. pp., 1113-1139.

Ruti, P.M., Somot, S., Giorgi, F., Dubois, C., Flaounas E., Obermann, A., Dell'aquila, A., Pisacane, G., Harzallah, A., Lombardi, E., Ahrens, B., Akhtar, N., Alias, A., Arsouze, T., Aznar, R., Bastin, S., Bartholy, J., Béranger, K., Beuvier, J., Bouffies-Cloché, S., Brauch, J., Cabos, W., Calmanti, S., Calvet, J.C., Carillo, A., Conte, D., Coppola, E., Djurdjevic, V., Drobinski, P., Elizalde-Arellano, A., Gaertner, M., Galàn, P., Gallardo, C., Gualdi, S., Goncalves, M., Jorba, O., Jordà, G., L'heveder, B., Lebeaupin-Brossier, C., Li, L., Liguori, G., Lionello, P., Maciàs, D., Nabat, P., Onol, B., Raikovic, B., Ramage, K., Sevault, F., Sannino, G., Struglia, M.V., Sanna, A., Torma, C., Vervatis, V., 2015. MED-CORDEX initiative for Mediterranean Climate studies. Bulletin of the American Meteorological Society, American Meteorological Society (in press).

Ryan, M.G., Law, B.E., 2005. Interpreting, measuring, and modeling soil respiration. Biogeochemistry, 73(1):3-27. Doi: 10.1007/s10533-004-5167-7

Sanchez-Cañete, E.P., Serrano-Ortiz, P., Domingo-Poveda, F., Kowalski, A.S., 2013. Cave ventilation is influenced by variations in the $\mathrm{CO}_{2}$-dependent virtual temperature. International Journal of Speleology, 42(1):1-8. Doi: 10.5038/1827-806X.42.1.1

Serrano-Ortiz, P., Roland, M., Sanchez-Moral, S., Janssens, I.A., Domingo, F., Godderis, Y., Kowalski, A.S., 2010. Hidden, abiotic $\mathrm{CO}_{2}$ flows and gaseous reservoirs in the terrestrial carbon cycle: Review and 
perspectives. Agricultural and Forest Meteorology, 151(4):529-529. Doi: 10.1016/j.agrformet.2010.12.005

Sillmann, J., Kharin, V.V., Zwiers, F.W., Zhang, X., Bronaugh, D., 2013. Climate extremes indices in the CMIP5 multimodel ensemble: Part 2. Future climate projections. Journal of Geophysical Research: Atmospheres, 118, 2473-2493. Doi:10.1002/jgrd.50188

Suchet, P.A., Probst, J.L., Ludwing, W., 2003. Worldwide distribution of continental rock lithology: implications for the atmospheric/soil $\mathrm{CO}_{2}$ uptake by continental weathering and alkalinity river transport to the oceans. Global Biogeochemistry Cycles, 17(2):1038. Doi:10.1029/2002GB001891

Sun, Q.Q., Shi, K., Damerell, P., Whitham, C., Yu, G.H., Zou, C.L., 2013. Carbon dioxide and methane fluxes: seasonal dynamics from inland riparian ecosystems, northeast China. Science of the total environment, 465:48-55. Doi: 10.1016/j.scitotenv.2013.01.036

Tang, J.W., Baldocchi, D.D., Qi, Y., Xu, L.K., 2003. Assessing soil $\mathrm{CO}_{2}$ efflux using continuous measurements of $\mathrm{CO} 2$ profiles in soils with small solid-state sensors. Agricultural and Forest Meteorology, 118(3-4):207-220. Doi: 10.1016/s0168-1923(03)00112-6

Tans, P.P., Fung, I.Y., Takahashi, T., 1990. Observational constraints on the global atmospheric $\mathrm{CO}_{2}$ budget. Science 247:1431-1438. Doi: 10.1126/science.247.4949.1431

Tramblay, Y., Ruelland, D., Somot, S., Bouaicha, R., Servat, E., 2013. High-resolution Med-CORDEX regional climate model simulations for hydrological impact studies: a first evaluation of the ALADINClimate model in Morocco. Hydrology and Earth System Sciences, 17:3721-3739. Doi: 10.5194/hess-173721-2013

Turcu, V.E., Jones, S.B., Or, D., 2005. Continuous soil carbon dioxide and oxygen measurements and estimation of gradient-based gaseous flux. Vadose Zone Journal, 4(4):1161-1169. Doi: $10.2136 /$ vzj2004.0164

Valladares, D.L., da Silva, A.A.R., Lacerda, T., Anjos, R.M., Rizzotto, M., Velasco, H., de Rosas, J.P., Tognelli, G., Yoshimura, E.M., Juri Ayub, J., 2014. Using ${ }^{222} \mathrm{Rn}$ as a tracer of geodynamical processes in underground environments. Science of The Total Environment, 468-469:12-18. Doi: 10.1016/j.scitotenv.2013.08.003 
Vargas, R., Baldocchi, D.D., Allen, M.F., Bahn, M., Black, T.A., Collins, S.L., Yuste, J.C., Hirano, T., Jassal, R.S., Pumpanen, J., Tang, J., 2010a. Looking deeper into the soil: biophysical controls and seasonal lags of soil $\mathrm{CO}_{2}$ production and efflux. Ecological Applications, 20(6):1569-1582. Doi: 10.1890/09-0693.1

Vargas, R., Detto, M., Baldocchi, D.D., Allen, M.F., 2010b. Multiscale analysis of temporal variability of soil $\mathrm{CO}_{2}$ production as influenced by weather and vegetation. Global Change Biology, 16(5):1589-1605. Doi: 10.1111/j.1365-2486.2009.02111.x

White, W.B., 2013. Carbon fluxes in karst aquifers: sources, sinks, and the effect of storm flow. Acta Carsologica, 42(2-3):177-186

Wood, W.W., 1985. Origin of caves and other solution openings in the unsaturated (vadose) zone of carbonate rocks: A model for $\mathrm{CO}_{2}$ generation. Geology 13, 822-824.

Xu, L., Baldocchi, D.D., Tang, J., 2004. How soil moisture, rain pulses, and growth alter the response of ecosystem respiration to temperature. Global Biogeochemical Cycles, 18(4). Doi: 10.1029/2004GB002281

Zanchi, F.B., Meesters, A.G.C.A., Waterloo, M.J., Kruijt, B., Kesselmeier, J., Luizão, F.J., Dolman, A.J., 2014. Soil $\mathrm{CO}_{2}$ exchange in seven pristine Amazonian rain forest sites in relation to soil temperature. Agricultural and Forest Meteorology, 192-193:96-107. Doi: 10.1016/j.agrformet.2014.03.009

Zornoza, R., Rosales, R.M., Acosta, J.A., de la Rosa, J.M., Arcenegui, V., Faz, A., Perez-Pastor, A., 2016. Efficient irrigation management can contribute to reduce soil $\mathrm{CO}_{2}$ emissions in agriculture. Geoderma, 263: 70-77. Doi: 10.1016/j.geoderma.2015.09.003 